Review

\title{
Energy Retrofit in European Building Portfolios: A Review of Five Key Aspects
}

\author{
Aurora Greta Ruggeri ${ }^{1}\left[\right.$, Laura Gabrielli ${ }^{2, * \mathbb{C}}$ and Massimiliano Scarpa ${ }^{2}$ \\ 1 Department of Management and Engineering, University of Padova, 36100 Vicenza, Italy; \\ aurora.ruggeri@student.unife.it \\ 2 Department of Architecture and Arts, University IUAV of Venice, 30123 Venezia, Italy; \\ massimiliano.scarpa@iuav.it \\ * Correspondence: laura.gabrielli@iuav.it
}

Received: 22 July 2020; Accepted: 8 September 2020; Published: 10 September 2020

\begin{abstract}
The research about energy efficiency in buildings has exponentially increased during the last few years. Nevertheless, both research and practice still cannot rely on complete methodologies tailored for building portfolios as a whole, because the attention has always been drawn to individual premises. Yet, energy efficiency analyses need to go beyond the single building perspective and incorporate strategic district approaches to optimize the retrofit investment. For this purpose, several aspects should be considered simultaneously, and new methodologies should also be promoted. Therefore, this paper aims to discuss energy retrofit campaigns in building portfolios, drawing an exhaustive and updated review about the challenge of jumping from the single-building perspective to a stock-based analysis. This research discusses the publications available on the topic from five key aspects that are all essential steps in achieving a complete and reliable study of energy efficiency at a portfolio level. They are energy modelling and assessment, energy retrofit design, decision-making criteria assessment, optimal allocation of (financial) resources and risk valuation. This review, therefore, advocates for joint consideration of the problem as a basis on which to structure further disciplinary developments. Research gaps are highlighted, and new directions for future research are suggested.
\end{abstract}

Keywords: building portfolios; decision-making process; economic valuation; energy assessment; building energy efficiency; risk analysis

\section{Introduction}

Energy efficiency is a key factor for environmental, social and economic development [1], being the main driver for the mitigation of climate changes [2]. A significant reduction in energy consumption, in fact, seems to be the most viable option to fight the current worldwide energy shortage [3] and promote environmental sustainability in the long-run [4].

However, while reducing the amount of energy employed in the industrial sector has traditionally been the aim of significant research [5], it is only recently that the scientific community is focusing on new strategies to improve energy efficiency in buildings and constructions. It is now clear that the building sector is highly energy intensive and plays a prominent role in energy saving and sustainability: the global existing building stock is responsible for almost $50 \%$ of the world's total energy consumption and $33 \%$ of greenhouse gas emissions. It is also imperative to underline that the majority of consumption is due to existing stocks rather than new constructions. Moreover, there already exists today approximately the $70 \%$ of what will be the building stock in 2050, and only one deep refurbishment cycle will be feasible during this timeframe [6]. Buildings' renovation rates are extremely low, and the turnover is very expensive. As a consequence, the major part of the 
reduction in energy consumption must be achieved through a deep retrofitting of existing stocks [7]. Energy enhancements in building portfolios must be strategically planned, and effective methodologies should be developed to help and guide public and private asset holders in stock management.

European legislation is strongly focusing on the deep decarbonization of wide building stocks. The revised Energy Performance of Buildings Directive (EU) 2018/844 [8], which updates and supplements both Directive 2010/31/EU [9] and Directive 2012/27/EU [10], exhorts each EU Member State to decarbonize their national stocks before 2050, promoting the cost-effective transformation of existing premises into nearly Zero Energy Buildings (nZEB) [9].

An energy efficient building stock would make a significant contribution to achieve the long term European target of diminishing greenhouse gas emissions by $80-95 \%$ in comparison to 1990 levels before 2050 [11], and to achieve the short-term milestone of a $40 \%$ reduction by 2030 [12]. In the new Directive 2018/844, EU Members are invited to encompass an overview of their national stocks, identify the worst performing buildings in the assets, and provide viable refurbishment cycles.

Thereby, in order to meet these Europeans requests, a methodological change in research and a different perspective are now required to pursue a sharp increase in energy retrofit rates of the housing stock, while new approaches and smart solutions need to be introduced.

Planning energy retrofit campaigns on large building stocks is a highly complex subject, and it involves countless problems since several issues should be addressed simultaneously, such as energy assessments, technical designs, economic analyses, environmental studies, social aspects or conservation concerns. Regarding a single building perspective, the scientific literature has fully responded to the existing problems, providing a body of work in energy/economy assessment techniques, new materials or smart technologies. Several decision-making strategies have already been introduced and tested. Nevertheless, as far as the authors have reviewed, the scientific literature is lacking still in tailored solutions for building stocks/portfolios considered as a whole.

This paper aims to delve into energy retrofits in building stocks, comparing the available studies, and drawing a comprehensive and up-to-date review. This analysis also identifies and discusses five key issues that are imperative steps in the planning of energy retrofit operations at a stock level, i.e., energy modelling and assessment, energy retrofit design, decision-making criteria assessment, optimal allocation of available resources and risk valuation. Several articles and some reviews have already individually assessed some of these aspects. However, the way this paper differs is that it provides an overall view of the problem, setting the basis for further disciplinary developments, conceptualizing previous results, and drawing directions for future research. This review also underlines the literature gaps and unsettled issues.

The forthcoming Sections are organized as follows. Section 2 explains the methodology adopted to accomplish this review. Section 3 illustrates a general overview of the search findings, while Sections 4-9 discuss the various approaches implemented in the literature on retrofit operations at a portfolio level. Section 10 outlines the literature gaps and the areas where further research is still required. Ultimately, Section 11 draws the conclusion of this analysis and points out possible future streams of works.

\section{Materials and Methods}

In this literature review, we followed a concept-centric methodology, as recommended in [13] and later clarified in [14]. Thus, some key concepts determine and organize the flow of the paper through a logical approach. Although the publications analyzed are very divergent and show heterogeneous results, it still has been possible to identify common grounds and discuss shared aspects. This paper also incorporates the strengths of some relevant previous reviews published in the fields of building energy assessment [15-17], building energy retrofit design [18], energy refurbishment decision making criteria [19], optimization methods applied to energy efficient investments [20,21], and uncertainty analysis in energy retrofits [22].

The review process we conducted is composed of the following steps: 
- Appropriate work boundaries were defined. Only Articles, Conference papers and Reviews written in English and dealing with the topic in European Countries were considered. Moreover, the search was limited to the subject areas of "Engineering", "Energy", "Environmental Science", "Business, Management and Accounting", "Economics, Econometrics and Finance", "Arts and Humanities" (referred to as built heritage), "Computer Science", "Material Science”, "Mathematics and Social Science".

- The search keywords, their synonyms, and Boolean operations were chosen. The online search was therefore defined as ("energ* retrofit" OR "energ* enhancement" OR "energ* efficien*" OR "energ* saving*" OR "energ* performance*" OR "energ* mapping") AND (build* OR "edifice" OR "propert*" OR "hous*" OR "real estate" OR "estat**" OR "dwelling*" OR "habitation") AND (portfolio* OR "stock*" OR "large asset*" OR "multi* build*" OR "wide asset*").

- Consultation of selected documents and papers from the databases Web of Science and Scopus, as they cover broad and significant publications about the review topic.

- Common key aspects were identified.

- Review, critique and comparison of the selected documents according to a review matrix procedure.

- Identification of shared approaches, problems, and unsolved literature gaps.

- Draft of future research directions.

\section{Search Findings and Review Scheme}

There was a significant difference in the number of findings when comparing the results obtained through the online search about energy efficiency in singular buildings versus energy efficiency in building portfolios. In order to accurately describe this comparison, we performed two separate online searches. The first search used the keywords and synonyms previously defined about "energy efficiency" and "buildings", leading to 17,521 documents. The graphs in Figure 1 present the distribution of publications by year, territory, type, and subject area. Whereas, in the second search, we combined the keywords about "energy efficiency" and "buildings" and "portfolios/stocks", which led to only 98 results (Figure 2).

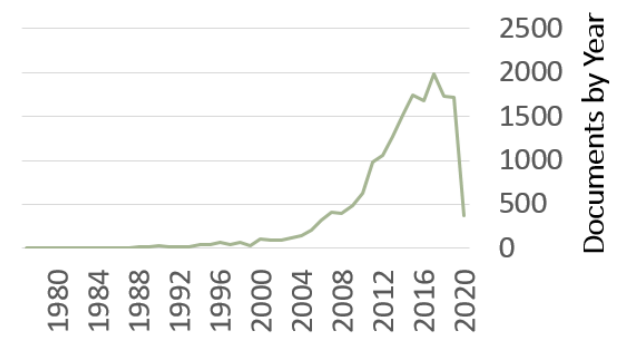

Subject Area

Arts and Humanities

Business, Management and Accounting

- Computer Science

Decision Sciences

Economics, Econometrics and Finance

Energy

- Engineering

- Environmental Science

- Materials Science

- Mathematics

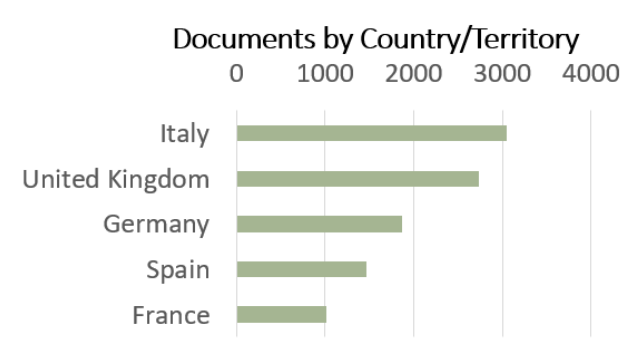

Type of Publication

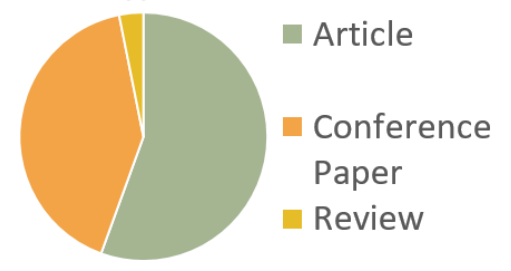

Figure 1. Documents by year, territory, type, and subject area on energy retrofit in building stocks (please, note that the number of publications for year 2020 was updated until 30 June 2020). 


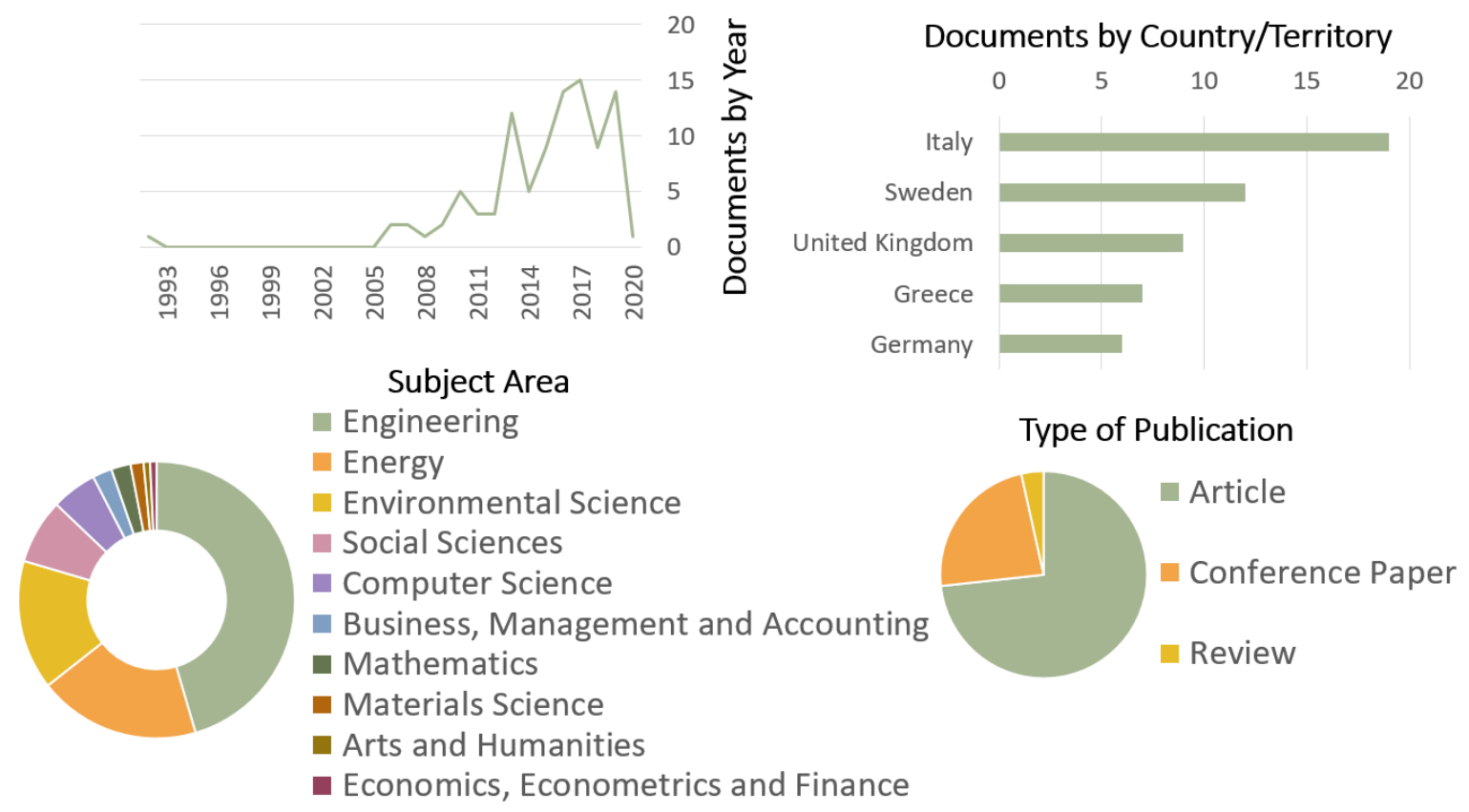

Figure 2. Documents by year, territory, type, and subject area on energy retrofit in building stocks (please note that the number of publications for year 2020 was updated until 30 June 2020).

As far as the first web search is concerned, we can state that much attention has been dedicated to energy efficiency in single buildings, and a large body of research now exists. Whereas, when it comes to the second search, a small amount of the literature is available, and a categorization of such a small number of studies has not been provided yet.

For this reason, this review paper will analyze the selected 98 documents (displayed in Table 1), organizing common problems and interpreting the achieved results.

Table 1. Publications concerning energy retrofit in building portfolios indexed in Scopus and Web of Science (Accessed on 30 June 2020).

\begin{tabular}{ccc}
\hline Type of Document & Not Open Access & Open Access \\
\hline Article & {$[23-83]$} & {$[6,84-91]$} \\
\hline Conference paper & {$[92-105]$} & {$[106-112]$} \\
\hline Review & {$[113-117]$} & \\
\hline
\end{tabular}

After every publication in Table 1 was accurately analyzed, it demonstrates that the methodologies employed are rather heterogeneous, and sometimes they even show conflicting results. Hardly any research proposes a comprehensive study, covering all the aspects that should be considered, from the early audits to the final decision-making processes. Indeed, the planning of energy retrofits in building portfolios is a highly complex issue, it requires multidisciplinary analyses, and numerous topics need to be managed at the same time, which makes it very difficult to perform a fully exhaustive study. 
In order to provide an organized theoretical understanding of the available literature, we created a "review matrix" where the details of a few fundamental issues were synthesized for each publication: five key aspects were chosen to be pointed out in the review matrix, and their definition was based on our previous working experience, on our research activities in the field of building energy retrofit, and on the consulted specific literature. These five issues, in our opinion, are all essential steps in achieving a complete and reliable study of energy efficiency at a portfolio level. They are:

1. Energy modelling and assessment. The energy consumption for each building has to be estimated in the as-is and in the design stages. This requires extensive information about building's materials, technologies and geometry, as well as data on the climate, installations, facilities, users' occupation schedule and behavior [15]. Each building has to be modelled into specific computer software or detailed statistic simulations so as to assess its energy requirements.

2. Energy retrofit design. A set of energy efficiency measures should be designed, taking into consideration the potentials and limits of each building. In general, it is better to study several alternatives (retrofit scenarios) to identify the best solution among them [18].

3. Decision-making criteria assessment. It is crucial to assess several decision-making criteria in order to compare and rank the alternative scenarios proposed. This may involve the evaluation of the produced energy savings, monetary savings, environmental benefits, capital expenditures or others [19].

4. Optimal allocation of resources. This fourth step regards the identification of the best energy efficiency measures over the portfolio as a whole, considering different objectives, under given constraints [20].

5. Risk valuation. Finally, the last issue involves risk assessment and quantification, so as to include the complex and variable nature of the problem [22].

We provide, as an example of the review process, a selection of 11 papers due to exhaustiveness and strategic approach, and we show in Table 2 the results according to the proposed review matrix scheme. For each paper, the five key aspects are summarized in a column in the table, therefore describing the energy assessment methodology, the retrofit measures adopted, the decision making criteria used, as well as the optimization and the risk valuation techniques employed.

The next five paragraphs will discuss each of the five aspects identified above, with the aim of finding common research lines, significant results or unsolved literature gaps. In each paragraph we first introduce general aspects of the issue, usually resulting from the literature dedicated to individual buildings, while in a second step we move the discussion to the building stock level, presenting the most significant papers from Table 1 . 
Table 2. Concept-centric review-matrix.

\begin{tabular}{|c|c|c|c|c|c|c|}
\hline Title & Case-Study & $\begin{array}{c}\text { Energy Modelling } \\
\text { and Assessment }\end{array}$ & Energy Retrofit Design & $\begin{array}{c}\text { Decision-Making } \\
\text { Criteria Assessment }\end{array}$ & $\begin{array}{c}\text { Optimal Allocation } \\
\text { of Resources }\end{array}$ & Risk Valuation \\
\hline $\begin{array}{l}\text { An analysis methodology for } \\
\text { large-scale deep energy retrofits } \\
\text { of existing building stocks: Case } \\
\text { study of the Italian } \\
\text { office building }\end{array}$ & $\begin{array}{l}\text { Existing Italian office } \\
\text { building stock. }\end{array}$ & $\begin{array}{l}\text { Detailed energy analysis and } \\
\text { energy modelling of } \\
\text { reference buildings in } \\
\text { Energy Plus }\end{array}$ & $\begin{array}{l}\text { Eight energy efficiency } \\
\text { measures are combined in a } \\
\text { range of different } \\
\text { possible scenarios }\end{array}$ & $\begin{array}{l}\text { LCC, energy savings, } \\
\text { cost-effectiveness }\end{array}$ & $\begin{array}{c}\text { Multi-objective } \\
\text { optimization, through a } \\
\text { Genetic Algorithm } \\
\text { optimization technique: } \\
\text { min. LCC, } \\
\text { max. energy savings }\end{array}$ & Sensitivity analysis \\
\hline $\begin{array}{c}\text { An approach for an educational } \\
\text { building stock energy retrofits } \\
\text { through life-cycle } \\
\text { cost optimization }\end{array}$ & $\begin{array}{l}\text { Educational building } \\
\text { stock in Istanbul }\end{array}$ & $\begin{array}{l}\text { Energy classification method } \\
\text { (energy classes) and } \\
\text { representative buildings }\end{array}$ & Energy retrofit scenarios & LCC, energy efficiency & $\begin{array}{l}\text { Cost-optimal approach, } \\
\text { GenOpt optimization tool }\end{array}$ & - \\
\hline $\begin{array}{l}\text { Energy retrofit alternatives and } \\
\text { cost-optimal analysis for large } \\
\text { public housing stocks }\end{array}$ & $\begin{array}{c}\text { Large housing stock } \\
\text { owned by a } \\
\text { semi-public real } \\
\text { estate company }\end{array}$ & $\begin{array}{c}\text { Energy calculations } \\
\text { implemented into a novel } \\
\text { tool called BQE (Building } \\
\text { Quality Evaluator) }\end{array}$ & $\begin{array}{l}\text { Thirteen energy retrofit } \\
\text { alternative scenarios }\end{array}$ & $\begin{array}{l}\text { Initial costs, NPV, } \mathrm{PB} \text {, global } \\
\text { cost, } \mathrm{CO} 2 \text { emissions, energy } \\
\text { performance indexes }\end{array}$ & $\begin{array}{l}\text { Cost-optimal analysis on } \\
\text { design alternatives }\end{array}$ & Sensitivity analysis \\
\hline $\begin{array}{l}\text { Analysis of the energy efficiency } \\
\text { potential of household lighting } \\
\text { in Switzerland using a } \\
\text { stock model }\end{array}$ & $\begin{array}{l}\text { Residential stock in } \\
\text { Switzerland }\end{array}$ & $\begin{array}{l}\text { Stock model for estimating } \\
\text { electricity consumptions due } \\
\text { to household lighting }\end{array}$ & Four scenarios & $\begin{array}{l}\text { cost-effectiveness, LCC, } \\
\text { energy savings }\end{array}$ & $\begin{array}{l}\text { Maximum energy savings } \\
\text { and minimum costs }\end{array}$ & Sensitivity analysis \\
\hline $\begin{array}{l}\text { A Decision Making Technique to } \\
\text { Optimize a Buildings' Stock } \\
\text { Energy Efficiency }\end{array}$ & $\begin{array}{l}\text { Stock of five public } \\
\text { school buildings in } \\
\text { Bari (Italy) }\end{array}$ & $\begin{array}{l}\text { Diagnosis and analysis on a } \\
\text { building-by-building basis }\end{array}$ & $\begin{array}{l}\text { Different retrofit actions } \\
\text { combined into } \\
\text { fourteen scenarios }\end{array}$ & $\begin{array}{l}\text { Application potential } \\
\text { (performance indicators), } \\
\text { costs, payoff }\end{array}$ & $\begin{array}{c}\text { Multiobjective } \\
\text { optimization algorithm } \\
\text { (Pareto optimal) followed by } \\
\text { a multiattribute } \\
\text { ranking procedure }\end{array}$ & - \\
\hline $\begin{array}{l}\text { Techno-economic potential of } \\
\text { large-scale energy retrofit in the } \\
\text { Swiss residential building stock }\end{array}$ & $\begin{array}{l}\text { Swiss residential } \\
\text { building stock }\end{array}$ & $\begin{array}{l}\text { Statistical analysis of more } \\
\text { than } 6000 \text { energy } \\
\text { performance certificates }\end{array}$ & $\begin{array}{l}\text { Energy retrofit measures } \\
\text { taken from the energy } \\
\text { performance certificates }\end{array}$ & $\begin{array}{l}\text { Investment and operating } \\
\text { costs, energy savings, NPV }\end{array}$ & Energy efficiency cost-curve & $\begin{array}{l}\text { Best estimate and } \\
\text { optimistic scenario }\end{array}$ \\
\hline $\begin{array}{l}\text { Addressing large-scale energy } \\
\text { retrofit of a building stock via } \\
\text { representative building samples: } \\
\text { Public and private perspectives }\end{array}$ & $\begin{array}{l}\text { Italian public } \\
\text { administration } \\
\text { building stock }\end{array}$ & $\begin{array}{l}\text { Representative building } \\
\text { samples and implementation } \\
\text { on the SLABE tool, } \\
\text { "Simulation-based } \\
\text { Large-scale uncertainty/ } \\
\text { sensitivity Analysis of } \\
\text { Building Energy } \\
\text { Performance" }\end{array}$ & $\begin{array}{l}\text { Retrofit packages found in } \\
\text { function of building location, } \\
\text { intended use and } \\
\text { construction type }\end{array}$ & $\begin{array}{l}\text { Global cost, primary energy } \\
\text { consumption, polluting } \\
\text { emissions }\end{array}$ & $\begin{array}{l}\text { Maximum energy-efficiency } \\
\text { (public interest) or minimum } \\
\text { global cost (private interest) }\end{array}$ & $\begin{array}{c}\text { Sensitivity Analysis } \\
\text { (SLABE) }\end{array}$ \\
\hline
\end{tabular}


Table 2. Cont

\begin{tabular}{|c|c|c|c|c|c|c|}
\hline Title & Case-Study & $\begin{array}{l}\text { Energy Modelling } \\
\text { and Assessment }\end{array}$ & Energy Retrofit Design & $\begin{array}{c}\text { Decision-Making } \\
\text { Criteria Assessment }\end{array}$ & $\begin{array}{c}\text { Optimal Allocation } \\
\text { of Resources }\end{array}$ & Risk Valuation \\
\hline $\begin{array}{l}\text { Progressive Energy Retrofit for } \\
\text { the educational building stock in } \\
\text { a Smart City }\end{array}$ & $\begin{array}{c}\text { Italian school } \\
\text { building stock in } \\
\text { Melzo, Northern Italy }\end{array}$ & $\begin{array}{l}\text { Building Information } \\
\text { Modeling (BIM) and energy } \\
\text { simulations in Edilclima }\end{array}$ & $\begin{array}{l}\text { Energy scenarios for } \\
\text { progressive upgrades }\end{array}$ & $\begin{array}{l}\text { Timing, costs, energy savings, } \\
\text { budget and return } \\
\text { on investment }\end{array}$ & Maximum energy savings & - \\
\hline $\begin{array}{l}\text { Using multi-objective } \\
\text { optimization for the integrated } \\
\text { energy efficiency improvement of } \\
\text { a smart city public } \\
\text { buildings' portfolio }\end{array}$ & $\begin{array}{l}\text { Existing stock of five } \\
\text { public buildings } \\
\text { located in Bari, Italy }\end{array}$ & On-site audit & $\begin{array}{l}\text { Seven alternative energy } \\
\text { efficiency actions }\end{array}$ & $\begin{array}{l}\text { Energy savings, } \\
\text { environmental sustainability, } \\
\text { internal comfort, costs, payoff }\end{array}$ & $\begin{array}{l}\text { Multi-objective optimization } \\
\text { algorithm and pareto } \\
\text { optimal retrofit }\end{array}$ & - \\
\hline $\begin{array}{l}\text { Decision support model for } \\
\text { energy-efficient improvement of } \\
\text { entire building stocks }\end{array}$ & $\begin{array}{l}\text { Four case studies: } \\
\text { school, public } \\
\text { multipurpose } \\
\text { building and two } \\
\text { kindergartens. }\end{array}$ & $\begin{array}{l}\text { On-site analysis and data } \\
\text { collection for buildings with } \\
\text { the highest energy } \\
\text { saving potential }\end{array}$ & $\begin{array}{l}\text { Various energy efficiency } \\
\text { measures: minimum } \\
\text { medium and maximum level }\end{array}$ & $\begin{array}{l}\text { Energy saving potential, } \\
\text { LCC, PBP }\end{array}$ & Optimize the saving potential & Sensitivity analysis \\
\hline $\begin{array}{l}\text { Cost effectiveness assessment } \\
\text { and beyond: A study on energy } \\
\text { efficiency interventions in Greek } \\
\text { residential building stock }\end{array}$ & $\begin{array}{l}\text { Existing residential } \\
\text { Greek building stock }\end{array}$ & Reference buildings & $\begin{array}{l}\text { Numerous combinations of } \\
\text { interventions proposed as } \\
\text { alternative design scenarios }\end{array}$ & LCC, PBP & Cost-optimal analysis & Sensitivity analysis \\
\hline
\end{tabular}




\section{Building Energy Modelling and Assessment}

\subsection{General Overview}

In general, building energy modelling and procedures can be categorized into top-down and bottom-up approaches [16,17], as illustrated in Figure 3. Top-down approaches study interactions between energy use and its main drivers [18], including demographic growth [118], macroeconomic indicators, constructions/demolitions rates, policy changes, market conditions, energy prices [119], weather [120], consumer preferences or technological innovation [121]. Top-down models are based on statistical techniques, such as regression analysis [122] or search algorithms [123], and they can be categorized due to the variables analyzed. Econometric models are primarily based on prices and incomes $[124,125]$. Technological models link the energy consumption to widespread building characteristics of the stock, while physical models rely on climate, weather, and temperature data [126]. Top-down techniques are based on aggregate information, which does not give sufficient knowledge of individual buildings and single energy end-use. These approaches can only represent energy consumptions at an aggregate level.

In bottom-up approaches, the energy consumption is, instead, related to more detailed end-use data. Since the level of detail is higher, the accuracy of the estimate is sufficient for a reliable forecast of the energy demand at the single building level. Bottom-up techniques are, in turn, divided into statistical and engineering methods. Bottom-up statistical methods identify the relationship between building characteristics and energy demand, relying on statistical inference. These methods work similarly to top-down strategies, sharing the strength of those techniques, but leading to more accurate results. Statistical methods include regression models [127-133], conditional demand analysis [134-137] and artificial neural networks [138-140]. Finally, bottom-up engineering methods simulate the building energy consumption by studying the thermodynamics that describe how the building (a thermodynamic system) interacts with the environment [141].

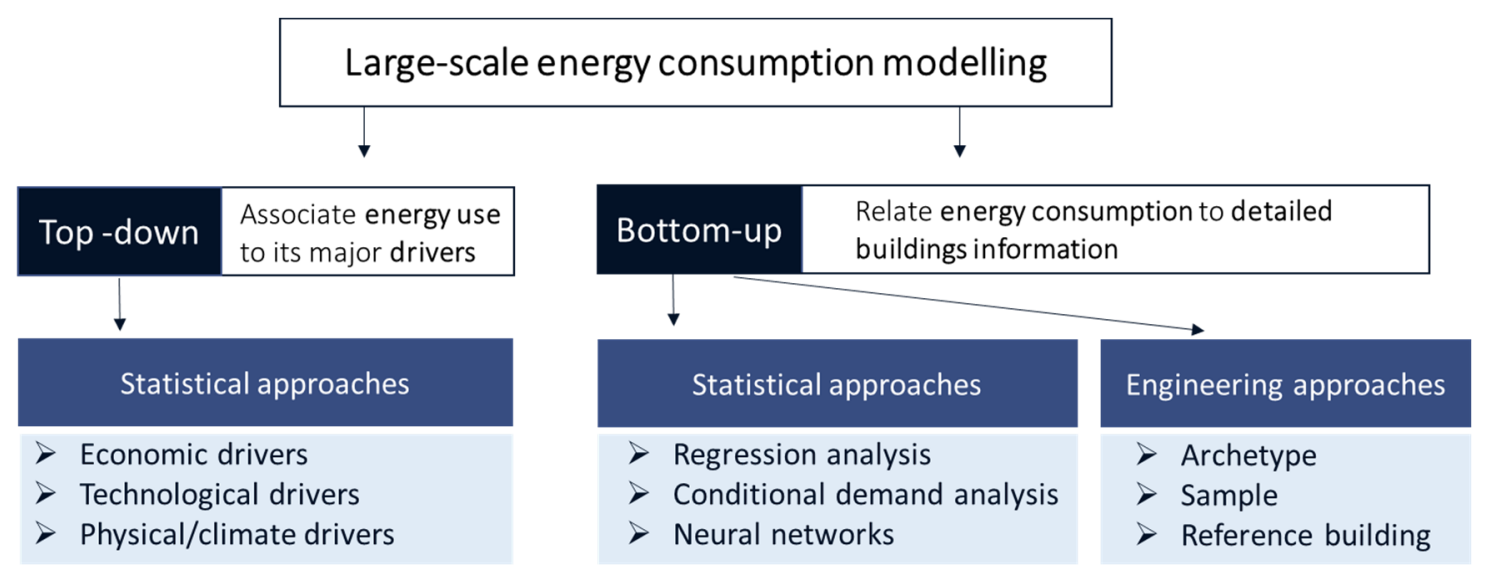

Figure 3. Building energy assessment techniques classification.

\subsection{Engineering Approaches in Building Stocks}

Bottom-up engineering approaches have been frequently applied in the literature for building energy assessment at a portfolio level. Since engineering methodologies are highly data-demanding, but it is not feasible to obtain a thorough knowledge of every single building in a vast stock, these kinds of approaches are usually based on reference building strategies and buildings' categories. A reference building can be defined as one building selected among the portfolio due to its ability to portray a building category or typology. The reference building is analyzed in-depth, so that some energy efficiency actions can be tested on it, as in single-building problems. The energy retrofit results obtained are extended to the building category through shared parameters (such as floor area, volume, or others). 
The European Authorities promoted the use of reference buildings as a feasible approach when acting on different building categories [142]. In this way, retrofit analyses could be carried out on reference buildings only, and the same improvements could be applied to other similar buildings as well.

From the documents in Table 1, we provide some examples of energy assessments at the stock level based on reference buildings, buildings categories, building types, typologies or representative case studies.

Significant research can be found in [26], where the authors developed a simulation-based approach aimed at evaluating retrofit programs for existing buildings portfolios. Their methodology was applied to the Italian office building stock, counting 64,911 edifices. The authors selected 30 reference buildings as good representatives of all the different building categories in the stock. Similarly, in [42], the authors adopted a reference building approach to study energy retrofit programs in the residential building stock in Greece. Another fundamental study can be found in [33], in which the author developed the so called "Facilities Energy Efficiency Model". It is a tool aimed at improving the energy consumption in building portfolios, comprehending the importance of planning measures and forecasting their impact. Similarly, in [79] the authors also developed a decision support system for a large housing stock in Italy. Three multi-function buildings in Bologna (Northern Italy) were selected as representative case studies, and the decision support system was tested on them. Another relevant work is presented in [84]; the authors analyzed an Italian building stock, creating 30 macro-categories of building typologies. The categories were defined according to five Italian climatic locations, three uses, and two types of envelope construction. For each category of buildings, the energy performance was assessed through the Simulation based Large scale uncertainty/sensitivity Analysis of Building Energy performance (SLABE) procedure previously discussed in [143] by the same authors. This work, thereby, represents a major step forward from the analysis of individual cases to a process orientation concerning energy efficiency in building portfolios as a whole.

Furthermore, in [24,92], the authors proposed a model for achieving the optimal energy efficiency level in building stocks. The case study in their research was a portfolio of five school buildings in Bari (South Italy). They analyzed energy consumption under a building-by-building perspective, through on-site analysis and detailed surveys, which was possible due to the size of the stock. In [96], the authors used building typologies and categories to calculate the total energy demand in several types of shopping center stocks located in France and Poland. In [81], ten buildings in Bologna (Italy) were considered as reference buildings to represent the housing stock, and different energy retrofit scenarios were tested according to the produced environmental and economic impact. The use of representative buildings or illustrative case studies were also embraced in $[86,100,102,109]$. The reference building approach is also at the center of the researches in $[47,55,106]$, according to the European building typologies defined in the Typology Approach for Building Stock Energy Assessment (TABULA) Project. The Energy Performance Indicator tracking Schemes for the Continuous Optimisation of refurbishment Processes in European housing stocks (EPISCOPE) project was, instead, illustrated in [99], and then applied in [52], contributing to the harmonization of the European building typology approach.

\subsection{Statistical Approaches in Building Stocks}

Other researchers have adopted statistical techniques to manage energy assessments in building portfolios. Since one of the major problems when performing statistical analyses to forecast energy consumption in building stocks is the collection of an appropriate database to perform statistical inference, several publications discussed possible solutions: many authors have stressed the need to improve and share knowledge about energy consumption patterns at a European level, and create common databases with uniform information, as discussed in [46,56]. In [110] the authors assessed various energy certification approaches, both mandatory and voluntary, and their potential applications in the energy efficient renovation of buildings portfolios. In [107], the authors performed a statistical analysis on approximately 6000 energy performance certificates of the Swiss residential building stock. The use of energy performance certificates as a statistical database to map actual energy performances 
and retrofit potentials in large building portfolios were also used on a Portuguese residential dwelling stock [70], in Spain for 129,635 existing buildings [63], in Sweden for 186,021 commercial buildings [64], as well as in Switzerland for 10,400 energy certificates [74] and in Greece, where the authors analyzed over 350,000 building certificates to achieve a better understanding of the Hellenic building stock [83].

In [37] the authors used statistical inference on an urban district in the city of Castellòn de la Plana (Spain), to predict energy requirements and discomfort hours according to five predictor variables, namely the street height-width ratio, the urban block typology, the building shape factor, the orientation, and the year of construction. In [85] the authors statistically analyzed the Homes Energy Efficiency Database, which is a database collecting information about approximately 13 million energetic improvements performed on existing buildings in UK over the past 15 years. With such a broad sample of data, the authors studied the impact of energy retrofit measures on energy demand, intending to support and target future investments. A hybrid method to calculate the energy demand in buildings was proposed in [51], where a regression analysis combined with building-physics based models was applied to a Danish residential stock. Then, ref. [88] analyzed the potential of implementing energy efficiency actions on the building stock in Cyprus, and identified policy solutions to enhance this potential.

Among statistical approaches, other authors developed building stock models to draw energy consumption patterns for entire stocks, both in their current state as well as in possible future scenarios. Stock models are an acknowledged tool to assess different building development paths at a city/region/country level. Such models are founded on the principle of mass conservation, and they are able to describe and quantify the flow of goods and materials through any system defined by spatial and temporal boundaries [29]. Building stock models can evaluate different retrofit strategies and help understand limits and potentials in the development of building portfolios [144]. They can draw future trends, acting as excellent support for portfolio management because they can establish long-term objectives connected to building energy consumption and $\mathrm{CO}_{2}$ emissions [145]. For instance, a dynamic building stock model was created to simulate the development of both size and age composition of dwelling stocks in 11 European countries [6], depending on the number of persons per dwelling, population, the dwelling's lifespan and renovation parameters. Another example can be found in [35], where again a building stock model was studied to analyze and forecast energy efficiency strategies for the German residential sector considering future projections of demolition/refurbishment rates and demand for floor space. A stock model was also developed in [29] to examine the energy efficiency potential in the Swiss household lighting, demonstrating the cost-effectiveness of switching to more efficient lighting technologies.

Other statistical approaches have been used in the literature, such as regression analyses or neural networks. The rebound effects of the energy saving potential was evaluated through a regression analysis in [50] for the Danish residential building stock. In [67], a regression analysis was also applied to the Swedish building stock, based on the energy performance certificates database merged with other data sources such as official registers and billing data. Artificial Neural Networks, instead, are at the basis of research in [48], and they assessed both the energy performance and retrofit actions in a non-residential building portfolio located in Southern Italy. Among bottom-up statistical methodologies, in $[54,68]$ a Geographical Information System (GIS) forecasted the energy consumption for the residential building portfolios in Carugate (a medium sized town in North Italy) and Rotterdam. In [49], the authors performed a preliminary energy audit and compared several energy retrofit simulations through a parametric calculation protocol for a portfolio of buildings including social housing in Reggio Emilia (Northern Italy). Finally, a new statistical approach to assess the energy demand in buildings (called E-SDOB, i.e., Statistical Distribution Of Buildings according to primary Energy use for heating) was applied in a real estate portfolio in Lombardy and Piedmont starting from Census data, and integrated with data from laws, the literature and standards [60]. A similar approach was also applied in five municipalities in Milan [53]. 


\section{Energy Retrofit Design}

\subsection{General Overview}

The second key aspect analyzed in this paper concerns the design of energy retrofit actions for building portfolios. According to [18], building retrofit measures could show three different orientations. The first focuses on the supply side, the second on the demand side, while the third addresses the changing of energy consumption patterns (Figure 4). Supply side retrofit measures involve the use of renewable energy [146,147] like solar thermal, photovoltaic [148], wind power, biomass or geothermal $[149,150]$. Several works presented the importance and significance of renewable energy use in buildings, suggesting programs, methods, and strategies to incorporate renewable sources in retrofit actions [151-155]. The most frequent type of energy measures in building retrofits concerns the demand side [156-163], where a decrease in a building's energy demand is achieved by introducing new technologies, thermal storage or heat recovery systems [164-167], or through the use of passive technologies [168] such as shading systems [169-172], natural ventilation [173,174] and site planning [175-177]. Lastly, building energy demand could also be significantly reduced simply by a change in energy consumption patterns [178,179]. This involves human factors or, in other words, how occupants decide to set their internal comfort criteria, as well as their energy related and environmental lifestyle including occupancy profiles, schedule, space use, intelligent control system, zonal heating or internal temperature [180-183].

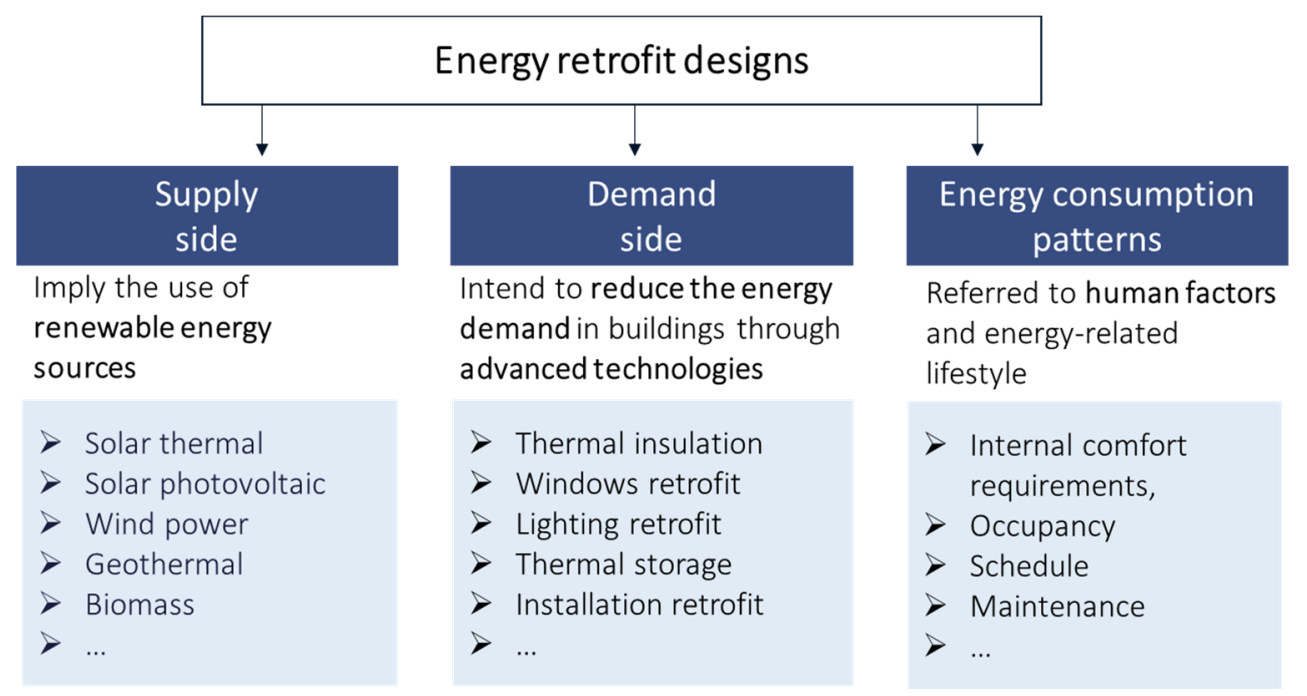

Figure 4. Building retrofit actions classification.

\subsection{Energy Retrofit Measures in Building Portfolios}

Amongst the most common retrofit actions analyzed in the literature to improve energy efficiency in building stocks, there are roof or wall thermal insulation, multi-glazed low-emissivity windows, high performance heat recovery in ventilation systems, automated climate control devices or renewable energy systems such as photovoltaic panels. Almost every study organizes the energy retrofit measures in different scenarios so as to compare several options. The goal is the investigation of different alternatives and the identification of the most effective one.

In [26], a list of eight energy efficiency measures was suggested and combined into numerous options, leading to 2,203,200 possible scenarios. The retrofit measures analyzed involved envelope thermal insulation, windows replacement, electric equipment, lighting fixture replacement, and heating, ventilation and air conditioning (HVAC) system upgrade. In [79], a list of various design measures included different kinds of thermal insulation (internal/external EPS or rockwool), window replacement, condensing boiler replacement, and photovoltaic systems. In [84], the authors suggested a series 
of energy retrofit measures based on buildings' particularities, namely, thermal insulation in polyurethane, replacement of windows with energy-efficient ones (PVC frames and multi glazed glass), and heating/cooling system replacement. In [86], eight retrofit actions were established, concerning heating/cooling system renovation and passive strategies (blinds or natural ventilation, heat recovery systems, lighting and use of solar energy). In [24], several different actions were also considered, divided into four categories: envelope, HVAC system, water equipment and lighting. In [42], numerous combinations of interventions were again proposed as alternative design scenarios, including thermal insulation, window replacement, shading systems, heating/cooling/domestic hot water installation replacement, photovoltaic panels, solar heating, and automation systems. In [44], a mechanical ventilation system with heat recovery was tested on two residential buildings, and a comparative analysis was conducted before and after its installation. Papers $[80,101]$ analyzed the energy use in the Swedish residential building stock in association with carbon dioxide emissions, comparing twelve energy saving measures which include the replacement of windows, lighting, hydro-pumps and ventilation systems. In [91], the authors compared several combinations of heating energy generation systems with the aim of understanding how they influence the energy requirements of the building. In Sweden, [104] tested both passive and active energy efficient technologies for multifamily buildings.

\subsection{Energy Retrofit Measures and Historic Buildings}

In some research, more specific and accurate energy efficiency measures are suggested when the retrofit is applied to cultural heritage buildings. The refurbishment of historic buildings is much more complex than for the rest of the housing building stock, because they are subject to heritage protection regulations [184]. It is essential to figure out how to reach sustainability targets without compromising the heritage value of historic buildings [185]. The retrofit measures have to be efficient and cost-effective, but also compatible with the conservation principles of architectural restoration [186]. In $[18,187]$, the authors presented two reviews of issues, problems, and methods for energy retrofits in historic buildings, stressing the importance of detailed on-site analysis and great accuracy in choosing the interventions to implement. Several studies have been applied to single buildings [188-192], while, at a portfolio level, only a few papers have addressed this important theme. It is indeed a hard task designing retrofit options in building portfolios including cultural heritage. Sometimes, interventions could be invasive, while, at other times heritage preservation comes first. Moreover, a designer should not overlook historic buildings' inherent properties, since they can provide a strong contribution in enhancing the energy efficiency. Otherwise, if designers neglect buildings' specific features, some retrofit measure could turn out to be counterproductive or even damaging [193]. Several problems could occur when the design is not thorough, well integrated and compatible with the buildings [194]. In [41], the author discussed the impact of sustainable technologies on historic dwellings, looking into the controversial problem of preserving the cultural value in heritage buildings and building stocks as well. In [40], the refurbishment potential of traditional buildings built before 1919 in Serbia is discussed in terms of heritage enhancement and preservation, while in [31] the authors analyzed the energy efficiency potentials and limits for different building vintages in the city of Stockholm. Lastly, ref. [27] studied a portfolio of social and historic importance built before 1945 in Liege (Belgium), focusing on peculiar buildings parameters and characteristics, in order to define five building typologies. In [81], the authors compared and discussed a deep regeneration process versus a shallow renovation hypothesis in a housing stock in Bologna including historic buildings, showing how the different energy saving solutions might or might not adapt in different contexts. In the 1'Eixample district in Valencia (Spain), a stock of 588 multi-story listed buildings was analyzed in [71] to find the best retrofitting measures enhancing the thermal behavior of the stock, without compromising its historical nature. Another example can be found in [58] where the aim is to integrate technical and economic analysis with cultural heritage preservation aspects. 


\section{Decision Making Criteria Assessment}

\subsection{General Overview}

The third pivotal issue analyzed for this work involves the decision-making criteria used to compare and rank energy retrofit alternative scenarios. Assessment rules vary considerably, and they are aimed at evaluating the performance and the sustainability of different designs. As stated in [19], assessment criteria could be categorized into environmental, economic and social ones, as in Figure 5. Environmental criteria measure pollution, greenhouse gases, $\mathrm{CO}_{2}$ emissions, or energy consumption during a period of analysis. When accounting for energy consumption, both the operating energy and embodied energy used over the lifecycle of a building should be included [195]. While the operating energy is defined as the amount of energy consumed by a building to satisfy its heating, cooling and electricity requirements, the embodied energy is the total amount of energy used in buildings and buildings' materials during the entire process of production, onsite construction, operation, final demolition and disposal [196]. The methodology that is able to account for operating as well as embodied energy in retrofit analysis is the Life Cycle Assessment (LCA) [197-203]. The more the enhancement measures increase the energy performance of a building, the lower the operating energy will be; nevertheless, this will also produce an increase in the total embodied energy hidden in the process [204]. It is worth questioning if a decrease in operating energy will still produce a positive balance under an LCA perspective [205].

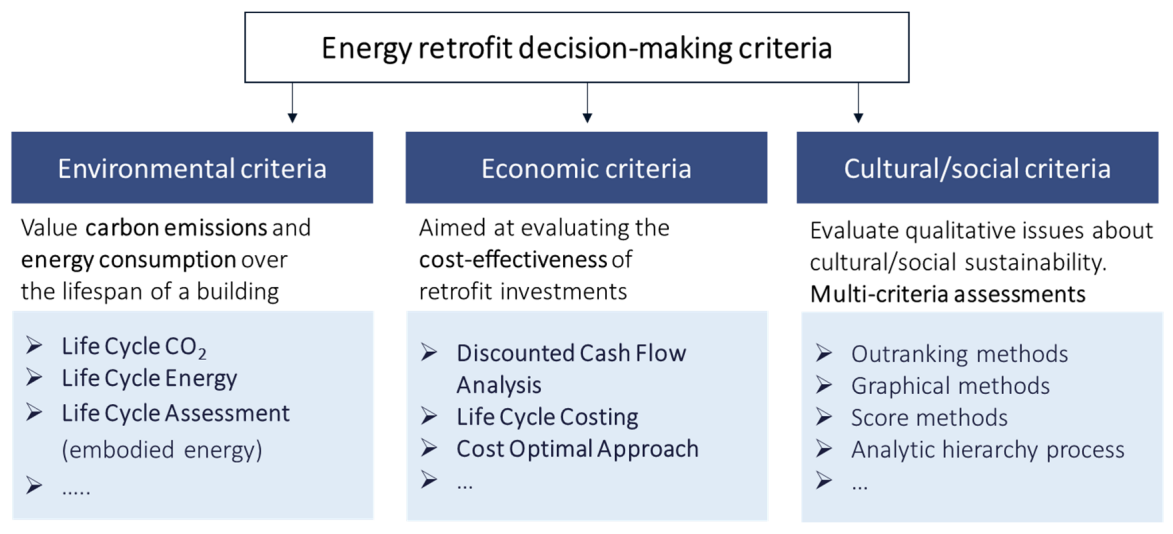

Figure 5. Assessment criteria: methods and techniques.

Conversely, economic assessment criteria are aimed at evaluating the cost effectiveness of retrofitting investments, so as to verify whether the monetary benefits produced will be able to cover (economic feasibility) and overcome (economic profitability) the costs sustained. The cash inflows are generated by the saving on energy consumption or by selling on site produced energy to the grid, while cost estimation can be performed using various techniques, including direct (comparison), indirect (bill of quantities) or mixed procedures [206-208]. With regard to social sustainability criteria, their assessment may seem less direct. In fact, while environmental and economic criteria can be easily measured and assessed due to their quantitative nature, other criteria may be harder to quantify, if qualitative issues about social, human or cultural factors are taken into consideration. Multi criteria assessments [209] help to quantify qualitative parameters, creating priorities among different alternatives, such as in outranking procedures or value-measurement models [210]. Several multi criteria approaches have supported building energy retrofits in single building analyses [211-213].

\subsection{Common Decision Making Criteria in Building Portfolios}

In the literature on building portfolio energy retrofits, cultural/social indicators have seldom been used, while health/human criteria have been employed more frequently, in relation to internal 
comfort or indoor health conditions. Environmental criteria are always taken into account, measuring reductions in energy consumption or $\mathrm{CO}_{2}$ emissions. However, the most common indicators supporting the decision making processes in building stock energy retrofits are the economic ones. They provide measurable and straightforward parameters to quantify the cost effectiveness of each design option, and they allow for the evaluation of economic feasibility of the interventions. Economic assessment techniques, such as the Life Cycle Cost (LCC) estimation [28,214-219] and the Discounted Cash Flow (DCF) analysis [220-222], rely on the same principles that property investment valuation is based on. Both LCC and DCF analyses allow the consideration of the time value of money [223], sharing the economic principle stating that future values need to be discounted back to the present in order to be compared, as described in $[224,225]$. The LCC analysis can be used to evaluate the economic feasibility of retrofit projects, considering all the expenses that occur during lifecycle of a building. This technique follows the Commission Delegated Regulation (EU) 244/2012 [142] defining the LCC, otherwise called global cost, as the sum of investment costs, future annual costs and residual value.

$$
L C C=\sum_{t=0}^{n}\left(\frac{C_{i}}{(1+r)^{t}}+\frac{C_{a n n}(1+g)^{t}}{(1+r)^{t}} \pm \frac{R_{v}}{(1+r)^{n}}\right), t \in \mathrm{N}\{0, \ldots, \mathrm{n}\}
$$

In the formula above, $C_{i}$ is the costs of investment, while $C_{a n n}$ is the annual costs for management and maintenance, and $R_{v}$ is the residual value. In addition, $g$ represents the growth rate on energy price, $r$ is the discount rate, $t$ is the time, and $n$ is the lifecycle of a building.

The DCF analysis also allows the assessment of the economic feasibility in energy retrofit projects: costs and savings are chronologically distributed along with a defined timeline, and they are discounted at their present value. The DCF analysis helps in understanding the cash flows related to a project. Among the traditional economic indexes associated with the DCF analysis there are the Net Present Value (NPV) [226,227], the Payback (PB) period [228], and the Internal Rate of Return (IRR) [229]. The NPV is defined as the present value of the cash flows of any project after a period of analysis, therefore representing the monetary benefit produced by the retrofit project. The NPV is calculated as follows [224]:

$$
N P V=\sum_{t=0}^{n}\left(-\frac{C_{i}}{(1+r)^{t}}+\frac{S_{v}(1+g)^{t}}{(1+r)^{t}}\right), t \in \mathrm{N}\{0, \ldots, \mathrm{n}\}
$$

$C_{\mathrm{i}}$ is the investment cost, $S_{v}$ is the future savings on energy consumption (post retrofit); again, $g$ is the growth rate on energy price, $r$ is the discount rate, $t$ is the time, while $n$ is period of analysis. The PB period of an investment is the time after which the initial cost is estimated to be recovered through the energy savings produced by the investment itself, while the IRR can be defined as the specific discount rate which makes the NPV equal to zero. The IRR can be useful to measure the profitability of energy investments, and, usually, it also represents the threshold at which the investment is considered to be economically viable.

\subsection{Decision Making Criteria in Building Portfolios: Practical Applications}

From the documents displayed in Table 1, some examples of assessment techniques and decision-making criteria employed in the literature to support energy retrofit in building stocks can be shown and explained. For instance, ref. [26] assessed each design scenario option through LCC analysis. Conversely, in [33] the author studied whether the savings achieved by energy retrofit designs were able to cover the investment costs. A key research is [79], where the retrofit interventions had to match five fundamental criteria, namely effectiveness, economic sustainability, environmental sustainability, adaptability, and compatibility. Special attention was also given in this research to the respect of artistic, cultural and contextual values of buildings. The economic/environmental indicators were all calculated through the Building Quality Evaluator (BQE), a novel tool previously developed by the same authors in [230], which assessed initial costs, global cost, $\mathrm{CO}_{2}$ emissions, NPV, 
PB period, and energy performance indexes in every design option. The NPV was analyzed for a 30-year timeframe, while the LCC calculation compared 10, 20 and 30-year periods of analysis.

On the contrary, in [84] three indicators allowed for the comparison among the design alternatives, namely LCC, primary energy consumption and pollution emissions. In [86], the authors also employed a LCC perspective to assess the economic benefits due to energy retrofit measures applied to a building stock in Romania. In [24], three competing criteria were employed to determine the optimal level of interventions. They were the application potential, the cost, and the payoff, where the application potential was the metric related to any retrofit action (e.g., surfaces), while the costs were modelled following a linear pricing model (product between unitary cost and application potential). In [62], both the energy consumption and the reduction in $\mathrm{CO}_{2}$ emissions were assessed for a non-residential building stock in Greece. School buildings were analyzed in [111], from a cost-optimal and cost-effective perspective, including the co-benefits of the renovation package. In [89], the energy consumption for space heating was used as a means to evaluate the quality of Rome's public school buildings. In [75], different energy savings options were compared under a financial NPV approach to forecast the total savings potential. Finally, in [42], the decision making process was performed through a LCC analysis over a 30-year timeframe, using the PB period indicator.

\section{Optimal Allocation of Resources}

\subsection{General Overview}

The fourth aspect addressed in this review involves the optimal allocation of available resources between the buildings in a portfolio. After various energy retrofit scenarios have been designed and compared through different assessment criteria, it is necessary to define which interventions, and on which buildings they should be applied, so that the optimal outcome can be achieved. Optimization processes help in identifying the best solution among the range of feasible alternatives. In building performance simulations, however, identifying the optimal result may not be referred to as being globally optimum, because it could represent an unfeasible solution due to the nature of the problem [231]. In [20], a detailed and up to date review compares the most frequent optimization methods employed in building energy efficiency. At the single building scale, optimization techniques are usually employed to identify the best trade off among design variables, e.g., insulation thickness or window to wall ratio. Some examples can be found in [232-235].

A clear classification of optimization strategies applied to building performance analysis is proposed in [21]. Basically, they can be defined due to the number/nature/type of design variables, number/nature of objective functions, presence/absence/nature of constraints and problem domains (Figure 6).

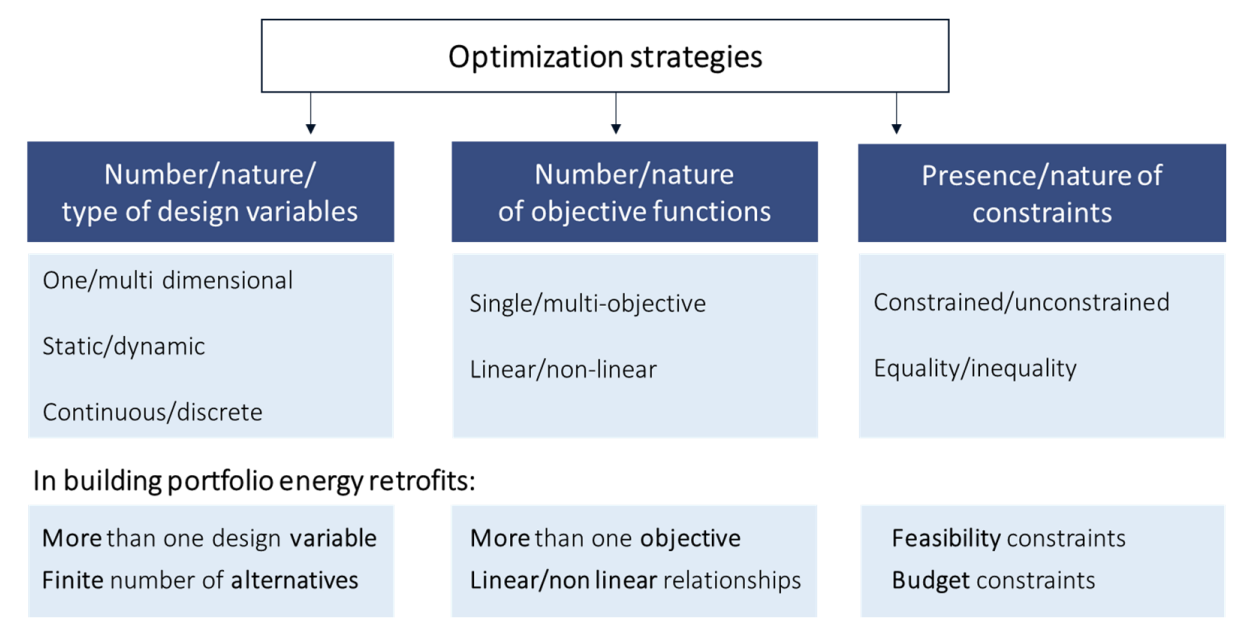

Figure 6. Classification of optimization methods and techniques. 


\subsection{Cost-Optimal Strategy in Building Portfolios}

In energy retrofits at a stock level, more than one design variable is necessarily analyzed due to the multi-faced structure of the problem. Design variables could be either dependent or independent from other parameters. Multiple objectives to achieve are identified, including economic, environmental, cultural or social objectives, within both feasibility and financial constraints as well.

Most of the time, the optimization process is structured as a cost-optimal analysis, performed on global costs and energy consumption. This methodology is required from the European Directive 2010/31/EU [9], where Article 2 defines the cost-optimal level as the energy performance design leading to the lowest whole cost over a predetermined lifecycle. In the cost-optimal calculation investment costs, maintenance and operating costs, as well as costs of disposal, have to be included. The EU Commission Delegated Regulation 244/2012 [142] has later clarified this approach, setting a methodological framework to estimate the cost-optimal levels of energy retrofits in buildings. In general, a cost-optimal analysis is graphically represented as in Figure 7. For any retrofit option, it is shown, on the $y$-axes, the related LCC (€EUR/year), while, on the $x$-axes, the corresponding energy consumption/energy savings $\left(\mathrm{kWh} /\left(\mathrm{m}^{2} \cdot\right.\right.$ year $\left.)\right)$.
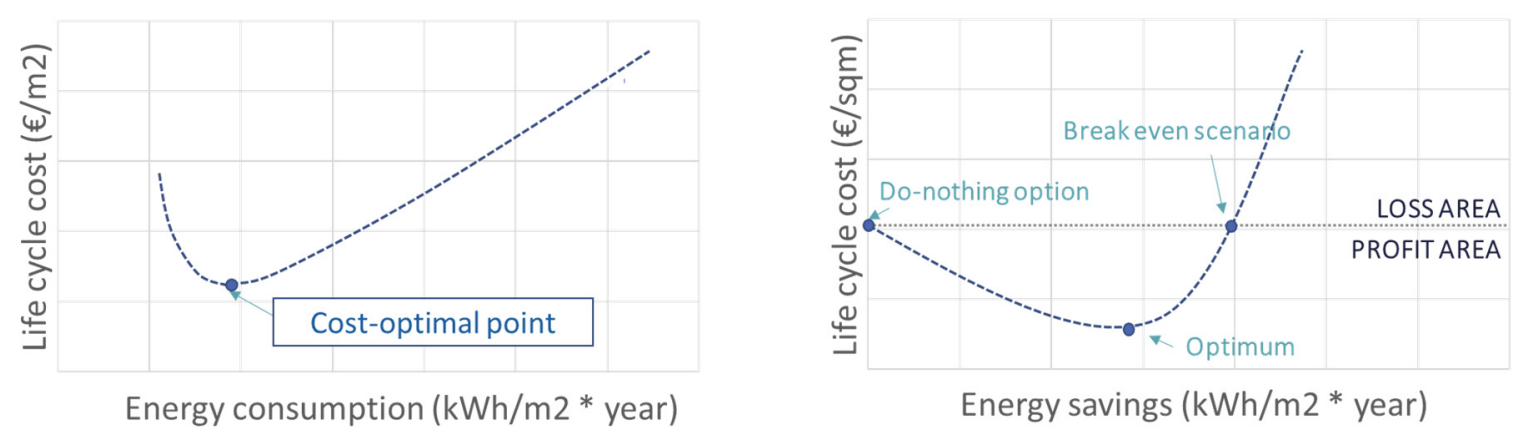

Figure 7. Cost-optimal analysis: qualitative graph.

The interpretation is quite intuitive: the cost-optimal graph enables the identification of the best level of retrofit intervention, which is the one that leads to the lowest LCC, however producing significant energy savings. In [42], the authors evaluated the cost-effectiveness of different design scenarios through a cost-optimal analysis, comparing the annual energy consumption with the related LCC. In [79], a cost-optimal analysis was also performed, with the goal of reaching nZEB standards. Under a different approach, in [84], the authors aimed to find the best retrofit level both following the Public Administration interest, minimizing pollution emission, and for a private stakeholder interest, minimizing the global cost. Otherwise, in [86] the authors identified the optimal retrofit scenario minimizing the overall LCC. Equally, in [26], the selection of the best set of actions was found through an optimization analysis, minimizing the LCC while maximizing primary energy savings. In [28], a cost-optimal approach was applied to an educational building asset in Istanbul in order to define the most convenient scenario in under the double perspective of energy and costs. In [87] the authors illustrated a cost-optimal approach to schedule maintenance and retrofit actions on a building portfolio owned by the Gothenburg municipal building company, in Sweden, with the aim of forecasting and optimizing the timing of efficiency measures.

\subsection{Beyond the Cost-Optimal Approach}

Besides energy consumption and global costs, some research included in the optimization process other indicators accounting for social, cultural or health elements, comfort indexes, pollutant emissions or technologies. For this purpose, the use of multi-attribute or multi-objective procedures is required in order to manage a multiplicity of criteria at the same time. In this direction, an important step was accomplished in [24], where the authors suggested a multi-criteria decision making tool aimed 
at determining the optimal energy efficiency strategy for entire stocks under multiple conflicting objectives, i.e., sustainability, energy efficiency, and internal comfort. They developed a decision-making technique organized in two phases: the first was a multi-objective integer optimization, and the second a multi-attribute ranking procedure. Instead, ref. [36] developed a systematic approach for energy efficiency portfolio optimizations in public buildings, coping with financial limitations while maximizing the possible benefits.

Ref. [72] developed a Pareto Optimization model, for the Madrilenian building stock, which combined Life Cycle Assessment and Life Cycle Cost so as to choose the retrofitting scenarios from both an environmental and financial point of view. Finally, ref. [94] assessed the economic viability of energy retrofit measures in the rental housing stock in Europe, taking into account, beyond the usual cost-optimal approach, a multi-dimensional perspective of numerous "added values" and the multiple beneficiaries of such investments.

\section{Risk Valuation}

\subsection{General Overview}

One last issue is still to be addressed: given that the projections in energy retrofit investments are so extended, risk and uncertainty are unavoidable analyses which must be undertaken. Energy retrofit results are associated with uncertainty, basically, because they rely on assumptions which are themselves affected by uncertainty. Different types of uncertainty may affect these studies, like unpredictable weather data [236], building envelope thermal properties [236], installation efficiency [237], energy use [238] or occupant behavior [239]. Even financial [240] and economic [241] parameters can produce a great deal of uncertainty in relation, for example, to the assessment of energy prices or discount/growth rates [242]. Moreover, investors have to bear huge capital expenditure, while decision makers deal with an unreliable forecast of prices, uncertain estimates of timing and costs, and hardly predictable trends in market parameters. Uncertainty strongly increases the cost of capital for energy efficiency investments, and it is one of the major barriers to such investments. It is worth noting that if all these points act as setbacks to the efficiency of single buildings, it is considerably more difficult when it comes to refurbishing a portfolio counting dozens of buildings.

\subsection{Uncertainties: Categories and Approaches}

As far as types of uncertainties are concerned, basically, uncertainty can be divided into model form uncertainty and parameter uncertainty [243,244]. Model form uncertainty, or model discrepancy, addresses weaknesses and flaws in computer programs about numerical approximations, inaccuracies, and missing physics [245]. Parameter uncertainty, instead, addresses the uncertain assessment of input values [246]. Moreover, many studies distinguish aleatory uncertainty from epistemic uncertainty. Aleatory uncertainty, also called variability or stochastic, is given by the natural variation of the system investigated, while epistemic uncertainty is a consequence of lack of knowledge, and could be theoretically eliminated by collecting more information. In general, it describes a dispersion of values, reflecting the individual heterogeneity for a given population, and epistemic uncertainty rises from lack of knowledge or incomplete information about a given parameter [247,248].

Risk and uncertainty management techniques can be organized into different categorizations. In [22], it is possible to find a comprehensive and up-to-date review of uncertainty analyses applied to building energy enhancements, which divides the methodologies into forward and inverse uncertainties. Forward uncertainty analysis, or uncertainty propagation, is based on quantifying and describing uncertainty in the inputs of a model so that uncertainty in the output can be assessed and measured. Instead, inverse uncertainty analysis [249], or model calibration, identifies unknown variables using mathematical models from measurement data. In energy retrofit analysis, forward uncertainty processes are the most frequently employed, because of the nature of the problem. 
Conversely, in [250], the authors divided risk management techniques into deterministic approaches, quantitative methods, and qualitative techniques (Figure 8).

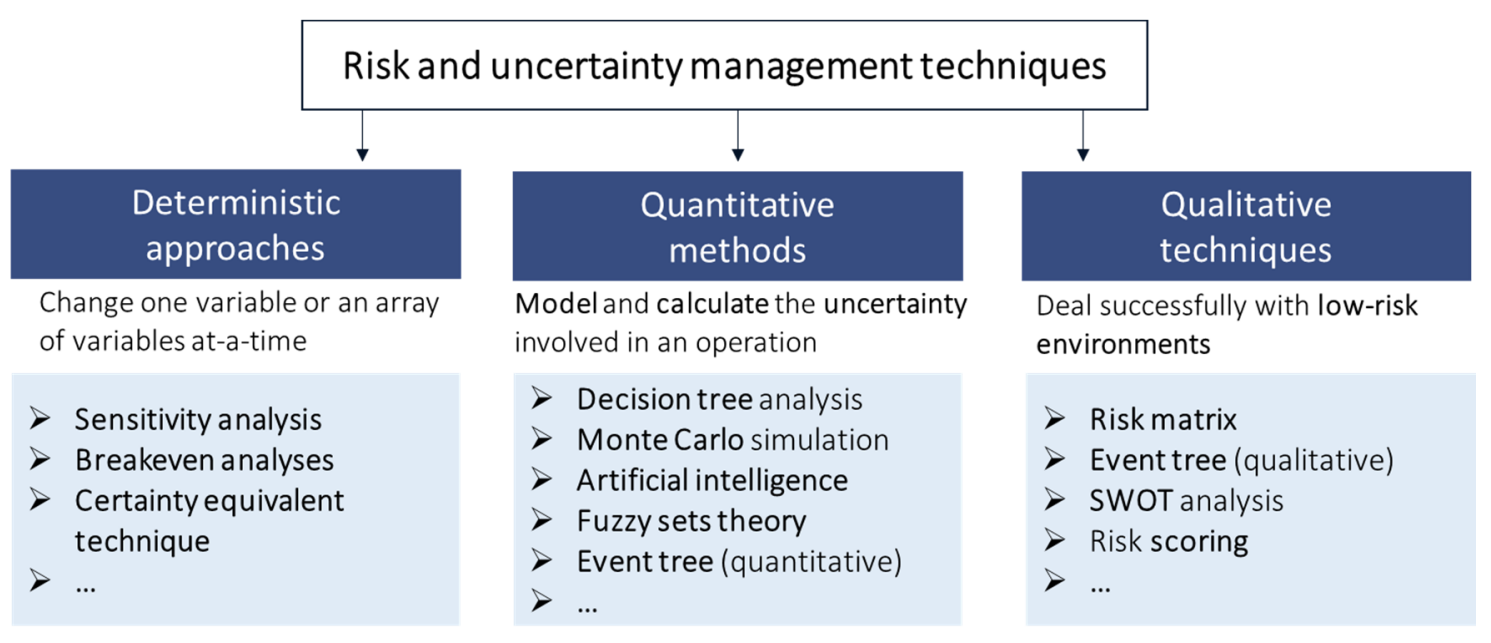

Figure 8. Risk assessment techniques.

Among the deterministic approaches, sensitivity analysis can be considered as the simplest way of coping with risk and uncertainty, since it belongs to the one-factor-at-a-time techniques [251]. Qualitative approaches cope with non-measurable parameters and include event tree, SWOT analysis (Strength, Weakness, Opportunity, Threat), risk matrix or risk scoring. Even if qualitative approaches are frequently employed in the specific literature for their flexibility in including qualitative issues, they are quite subjective methodologies and they can therefore only deal with low risk environments. Quantitative techniques allow instead the measurement and quantification of the risk. Quantitative approaches include decision tree analysis, artificial intelligence, fuzzy sets theory or the Monte Carlo simulation (MC). The latter is among the most useful techniques in the field of building energy efficiency because of its versatility [215,252]. The MC simulation can be employed in its simple version [253] or in three other extensions: the two-dimensional MC simulation (2D MC) [254,255], the incremental sampling method [256] and the surrogate model based MC method [257].

\subsection{Sensitivity Analysis in Building Stocks}

Almost all the analised papers from Table 1 employed a sensitivity analysis to include uncertainty aspects in their research. The EU Commission Delegated Regulation 244/2012 [142] promotes the use of a sensitivity analysis on several uncertain input data, such as discount rates, energy prices, or investment costs. The purpose is to identify the most critical factors in an energy retrofit investment. Sensitivity analysis allows the observation of the changes in a model output due to variations in input values. Since each input in the forecast model is varied one by one, it is easy to understand which impacts the most on the outcome. It is highly important to determine the most influential factors, so that the decision maker can monitor closely those variables that are essential to guarantee the viability of the investment. A tornado diagram, as in Figure 9, is generally employed to display sensitivity analysis results, showing the relationship between each input factor and their impact on the output: the more extended bars produce a higher impact on the outcome, while smaller bars do not.

Spider graphs could also represent sensitivity analysis findings, as shown in Figure 10. The spider plot demonstrates again how the output reacts to percentage/percentile deviations of inputs from their best estimate. The higher the slope, the greater the impact. 

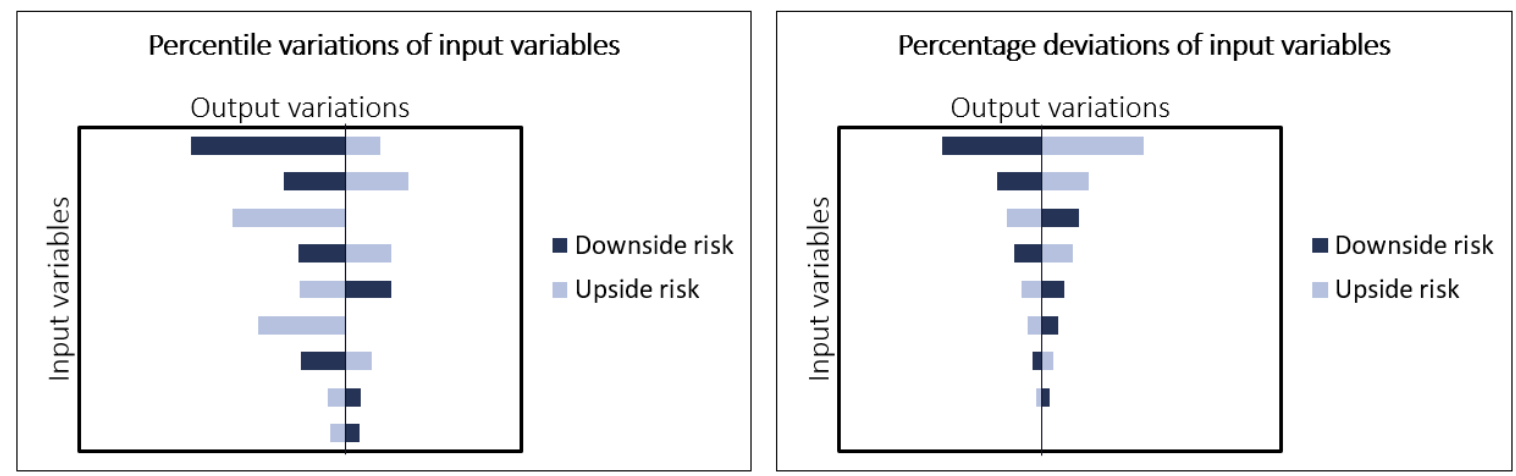

Figure 9. Tornado diagram: qualitative graph.

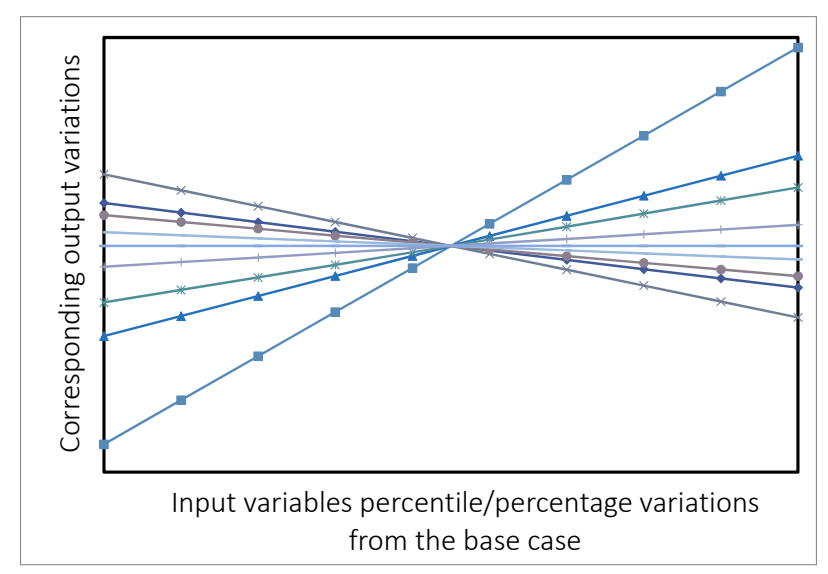

Figure 10. Spider plot: qualitative graph.

In [26], a sensitivity analysis was applied to the investment costs, the discount rate and the timeframe of the project, to determine their impact on the energy demand. The authors found that if the discount rate increases, the LCC values will decrease, lowering the optimal level of interventions, making energy efficiency investments less attractive. Conversely, longer lifetimes will make energy efficiency investments more attractive and cost-effective since the energy savings on consumption will increase.

As seen in [33], a sensitivity analysis tested output variations corresponding to changes in outside climatic conditions, energy cost, envelope thermal properties or usage schedule. The most influential factors on energy saving potential were found to be annual full load utilization hours, end-energy expenditures and temperature. Again, in [79] the authors demonstrate how energy price escalation rates impact on cost-optimal results through a sensitivity analysis. Two other applications of sensitivity analysis are in $[42,86]$. In [86], the authors employed a sensitivity analysis to capture changes that may occur in the following key variables: investment costs, maintenance costs, energy price. In [42], a sensitivity analysis studied the impact of variations in the discount factor and the growth rate of energy price: as the discount rate increases, the LCC decreases. If the interest rate, instead, decreases, the LCC will increase, and the cost-optimal point will be shifted towards more capital intensive and efficient technologies. In [69], the authors assessed possible uncertainty sources in a building stock in Sweden, comparing four uncertain factors i.e., global climate models, regional climate models, emissions scenarios and initial conditions. In [78], the uncertainties related to a set of energy saving measures, as well as to the achievable savings, were analyzed. A sensitivity analysis was also employed in [59] to test how variations in building age, envelope, HVAC system and compactness ratio (S/V ratio) will affect the primary energy requirement.

Instead, the Monte Carlo approach was used in [61] in combination with a bottom-up housing stock model. The aim of the research was the prediction of the energy demand in Portugal, and the 
authors used the Energy Performance Certification database to develop the probability distribution characterizing the Monte Carlo simulation.

\section{Other Issues}

Other specific issues have been occasionally addressed in the literature when dealing with energy efficiency actions in building portfolios. Among these, some authors focused on the indoor environmental quality [105] or on health impacts produced by energy retrofits [98]. Other examples are in [95], where the authors developed an assessment protocol to evaluate the implications that energy retrofit actions in existing stocks produce on indoor environment and public health, while in [97] the authors demonstrated how environmental indoor quality was affected by energy efficient technologies in Northern Europe. The research in [112] explored the impact that energy renovation measures in residential buildings in Slovakia would produce on thermal comfort and indoor air quality during the cold season. In [30], the indoor air quality was also analyzed for two different stocks in Finland and Lithuania, and the results achieved were proposed as recommendations for health programs and policies.

Meanwhile, user behavior, schedules and occupancy patterns were investigated considering how they influence real energy consumption in comparison to simulated data, both for the UK domestic housing [73], and for the Mediterranean social housing stock in Southern Spain [57].

On a different stream of work, the authors in [38] developed a cost performance indicator curve in order to plan and manage energy efficiency actions in building portfolios in the most cost-effective way, reducing construction costs and increasing net benefits. Turning to another issue, ref. [25] analyzed the number of net jobs produced by the most common energy retrofit designs for a Portuguese building stock. Other studies focused on the economic effects of investing in energy efficiency programs for large assets. For instance, ref. [34] analyzed the economic impact of investments in building energy efficiency at a national level in Finland, forecasting positive net benefits, while ref. [32] investigated the capitalization of retrofit actions both in rent and asset value through a hedonic regression model, applied to a French corporate real estate portfolio.

Obstacles and barriers to energy efficiency investments in Europe were discussed in [103] by surveying homeowners in five EU Member States. Conversely, ref. [39] developed detailed stock models to analyze in $27 \mathrm{EU}$ countries the potential of additional policy options to improve energy efficiency actions in residential buildings, considering energy demand, greenhouse gases emissions and costs. In [76], critical areas related to energy efficiency implementation in Sweden were investigated combining a literature survey with interviews. EU policies were discussed in $[65,77]$, to verify how implementing the European Energy Performance of Buildings Directive will impact on building stocks in Cyprus. Ref. [66] investigated how multi-level governance in Dutch housing was affecting the outcomes of policies aimed at decarbonizing the existing stock.

Other research combined the energy analysis of building stocks with Building Information Modelling (BIM) processes. BIM technologies are fundamental for structuring the building's information system, helping in the management and control of retrofit processes. The study in [93], for example, analyzed the application of a BIM procedure to produce and extract data during the energy retrofit and future management of a school building stock in Melzo, Northern Italy. The use of a Building Information System (BIS), instead, was discussed in [90] to demonstrate how a ready-to-use information package is very significant for the pursuit of collective interests in energy savings, supporting policy makers and defining urban sustainability strategies. The BIS process was tested by the authors on the Gavardo Municipality in Italy.

Finally, from the literature summarized in Table 1, some other reviews were also found: ref. [113] addressed energy management and behavioral changes in commercial and institutional buildings, ref. [114] discussed energy efficiency measures and the thermal rehabilitation in residential building stock located in Romania. In [115] the authors examined the effects of implementing the Energy Performance of a Buildings Directive on a 15-building stock in order to compare the impact produced 
by different energy saving measures, while ref. [116] reviewed the state-of-the-art in urban building energy modelling to identify the key elements. The review in [117] showed how building stock models included risk analysis, pointing out that the most common approaches were sensitivity analysis, comparative analysis and empirical studies. The review also stresses that in all the analized applications, a sensitivity analysis does evaluate the level of confidence of the results, but does not directly allow the reduction of risk and uncertainty for retrofit operations.

\section{Results and Discussion: Literature Gaps and Research Challenges}

To sum up, the research dedicated to energy retrofit at the building portfolio level offers some examples of single buildings analysis widening to entire stocks through a reference building strategy or by statistical approaches. Optimization studies can offer strong support to decision-making processes, usually through a cost-optimal perspective, while sensitivity analysis is certainly the most popular technique for capturing risk and uncertainty. In any case, the research is clearly lacking in the number of publications explicitly addressing the topic in a holistic way, covering its multidisciplinary and complex nature. Table 3 shows a general summary of the aspects dealt with.

Table 3. Critical summary scheme.

\begin{tabular}{|c|c|c|}
\hline Aspects & Method/Technique & Reference \\
\hline \multirow{4}{*}{$\begin{array}{l}\text { Building energy } \\
\text { modelling and } \\
\text { assessment }\end{array}$} & $\begin{array}{l}\text { Reference building/on site analysis for case } \\
\text { studies (Engineering simulation software) }\end{array}$ & $\begin{array}{c}{[24,26,28,33,42,47,52,55,59,74] \text {-(archetype) }} \\
{[79,81,83,84] \text {-(representative buildings samples) }} \\
{[86,92,96,102,106,108,111]}\end{array}$ \\
\hline & Energy Mapping & {$[63,64,70,74,83]$} \\
\hline & Stock model & {$[6,29,35,39,43,61]$} \\
\hline & Statistical approaches & {$[32,37,43,44,48,50,51,54,67,68,85,107]$} \\
\hline \multirow{3}{*}{ Energy retrofit design } & Different actions & {$[24,33,79,84,91,92,100,104]$} \\
\hline & Alternative scenarios & $\begin{array}{c}{[26,28,29,35,39,49,53,69-72,78,81,86-88,90,93,107} \\
116]\end{array}$ \\
\hline & Historic buildings & {$[27,31,40,41,58,71,89]$} \\
\hline \multirow{4}{*}{ Decision-making criteria } & Environmental criteria & $\begin{array}{c}{[24-26,29,30,33,45-47,49,55,57,72,79,84,92,101} \\
112]\end{array}$ \\
\hline & $\begin{array}{l}\text { Economic criteria: Discounted Cash } \\
\text { Flow Analysis }\end{array}$ & {$[24,33,75,79,92,107]$} \\
\hline & Economic criteria: Life Cycle Cost/costs & {$[24,26,28,29,33,72,79,84,86,87,92,107]$} \\
\hline & Social/cultural criteria & [29] \\
\hline \multirow{4}{*}{$\begin{array}{l}\text { Optimal allocation } \\
\text { of resources }\end{array}$} & Cost-optimal approach/cost-effectiveness & {$[26,28,29,38,39,42,47,79,84,87,94,106,111]$} \\
\hline & Minimum Life Cycle Cost & {$[26,86]$} \\
\hline & Optimization algorithms & $\begin{array}{c}{[24,26] \text {-(genetic algorithm) }} \\
{[28,36,84,106] \text { - (sequential }} \\
\text { search-optimization technique) } \\
{[92]}\end{array}$ \\
\hline & Multicriteria/multiattribute analyses & $\begin{array}{c}\text { [24]-(multicriteria characterization matrix) } \\
{[72]}\end{array}$ \\
\hline Uncertainty & Sensitivity analysis/Monte Carlo Simulation & {$[26,29,33,35,42,59-61,72,79,84,86,117]$} \\
\hline \multirow{5}{*}{ Other issues } & Rent/asset value of energy efficiency & [32] \\
\hline & $\begin{array}{l}\text { BIM/BIS (Building Information } \\
\text { Modelling/System) }\end{array}$ & {$[90,93]$} \\
\hline & Indoor environmental quality & {$[44,95,97,98,105,112]$} \\
\hline & Impact on jobs & [25] \\
\hline & $\begin{array}{c}\text { National } \\
\text { strategies/Roadmaps/Opportunities/Barriers } \\
\text { to investment/future directions }\end{array}$ & $\begin{array}{c}{[6,7,34,39,46,52,56,57,59,62,63,66,68,70,73,74,76} \\
\quad 77,82,86-88,90,94,99,106,109,110,113-115]\end{array}$ \\
\hline
\end{tabular}


Table 3. Cont.

\begin{tabular}{|c|c|c|}
\hline Aspects & Method/Technique & Reference \\
\hline New methodologies & $\begin{array}{l}\text { Tailored methodologies for } \\
\text { building portfolios }\end{array}$ & $\begin{array}{c}\text { [24,92]—-two step decision making technique, } \\
\text { [33]-Facilities Energy Efficiency model, } \\
\text { [58]_MARS-Maintenance and Renovation } \\
\text { Scheduling, } \\
\text { [79]_BQE Building Quality Evaluator, } \\
\text { [80]_ECCABS (Energy, Carbon and Costs } \\
\text { Assessment for Building Stocks), E-SDOB } \\
\text { (Statistical Distribution Of Buildings according to } \\
\text { primary Energy use for heating), } \\
\text { [84]_SLABE Simulation based Large scale } \\
\text { uncertainty/sensitivity Analysis of Building } \\
\text { Energy Performance. }\end{array}$ \\
\hline
\end{tabular}

- With regard to the first aspect analyzed, the energy assessment, it can be concluded that the most frequent approach used in research is the definition of reference buildings and buildings' categories. This strategy shows different merits and is a clever screening tool, even though it may not lead to sufficiently reliable and detailed forecasts, and further investigations may still be necessary. Some errors may occur in the calculation of energy consumption because each building shows different thermodynamics and should be analyzed on its own, rather than as a part of a broad building category. Stock models capture general developments and forecast future projections of the energy consumption at a macroscopic level, but they do not provide sufficiently detailed end-use information to act as reliable energy assessment techniques. Statistical approaches can be adopted but attention must be payed to the level of detail considered. Ultimately, the research gap is quite clear here: a lack of a shared methodology for assessing energy consumption at a portfolio level is evident. There is a great deal of hesitation in identifying the most suitable technique to use, in order to guarantee a rapid but also reliable forecast of the energy demand, without being excessively data demanding and time consuming.

- Conversely, the literature gap is not as evident as for the second and third aspects discussed, namely the energy retrofit measures and the assessment criteria employed in this type of analyses. The energy retrofit measures designed are unanimous among the authors. They are proved to be effective and successful, and their organization into a set of alternative scenarios is definitely a winning strategy. The decision-making criteria are also well defined. They refer to economic, environmental, cultural, human or social aspects, covering the multifaceted nature of energy retrofits. However, troubles may arise when the analysis is moved from the single building scale to the stock level. It could be necessary to add some new considerations to help managing numerous buildings at the same time, perhaps by introducing grouping and cluster analyses.

- The fourth aspect analyzed is the optimization strategy used by the authors to allocate the available resources among several buildings in an asset. This is usually based on a cost-optimal approach, maximizing the energy savings while minimizing the total costs. Although this approach is unquestionably useful and effective, it may overlook the synergy among the multiple goals involved in these kinds of analyses, sometimes even neglecting financial or technical constraints.

- The last issue discussed regards risk and uncertainty. Left out completely in some studies, it is generally a sensitivity analysis, which verifies the influence of variations in model inputs produced on model outputs. It goes without saying that energy retrofit operations would require much more rigorous risk simulation techniques, and the research gap is therefore obvious. Still, it is necessary to identify a methodology capable of dealing with the huge investment costs, the very long projections over time, the uncertain estimations of model parameters (energy price, costs, discount rate or others), and the stochastic nature of the variables involved (such as consumer behavior, climate or others). In conclusion, Table 4 compares the strengths and weaknesses of the methodologies previously discussed. 
Table 4. Strengths and weaknesses of current approaches.

\begin{tabular}{|c|c|c|c|}
\hline Aspect & Method/Technique & Strengths & Weaknesses \\
\hline \multirow{4}{*}{ Energy assessment } & $\begin{array}{l}\text { Engineering software } \\
\text { simulations }\end{array}$ & $\begin{array}{l}\text { Good accuracy and reliability, } \\
\text { intimate knowledge of the } \\
\text { building, capture the } \\
\text { thermodynamic behavior of } \\
\text { the building. }\end{array}$ & $\begin{array}{l}\text { Require too detailed end-use } \\
\text { information, very time consuming, } \\
\text { need specialized workforce, need } \\
\text { to model each building of the } \\
\text { stock. }\end{array}$ \\
\hline & Reference buildings & $\begin{array}{l}\text { Quick application, only a few } \\
\text { data required (per portfolio), } \\
\text { easy implementation. }\end{array}$ & $\begin{array}{l}\text { Not sufficiently reliable in } \\
\text { describing every building. }\end{array}$ \\
\hline & Stock models & $\begin{array}{l}\text { Forecast future consumption } \\
\text { patterns, draw future trends, } \\
\text { work at city/regional/ } \\
\text { urban scale. }\end{array}$ & $\begin{array}{l}\text { Do not provide enough details of } \\
\text { each single building in the stock. }\end{array}$ \\
\hline & Statistical approaches & $\begin{array}{l}\text { Acceptable accuracy and } \\
\text { reliability, provide a fast } \\
\text { assessment of the } \\
\text { consumption, do not require } \\
\text { excessively detailed } \\
\text { information of the buildings, } \\
\text { relatively easy } \\
\text { implementation. }\end{array}$ & $\begin{array}{l}\text { Require a wide database to draw } \\
\text { an inference and perform } \\
\text { statistical simulations. }\end{array}$ \\
\hline \multirow{4}{*}{ Assessment criteria } & $\begin{array}{l}\mathrm{LCA} / \mathrm{LCCO}_{2} / \mathrm{LCE}: \text { Life Cycle } \\
\text { Assessment } / \mathrm{CO}_{2} / \text { Energy }\end{array}$ & $\begin{array}{l}\text { Assess environmental impacts } \\
\text { of energy retrofits, consider a } \\
\text { cradle-to-grave perspective. }\end{array}$ & $\begin{array}{l}\text { It is very difficult to predict the } \\
\text { environmental impact/energy } \\
\text { consumption over a life cycle } \\
\text { period for a building (production, } \\
\text { operation, disposal). }\end{array}$ \\
\hline & $\begin{array}{l}\text { DCFA: Discounted Cash } \\
\text { Flow Analysis }\end{array}$ & $\begin{array}{l}\text { Considers the time } \\
\text { distribution of cash flows, } \\
\text { allows to control inflows and } \\
\text { outflows year by year. }\end{array}$ & $\begin{array}{l}\text { Does not include environmental } \\
\text { benefits, it is not considered a life } \\
\text { cycle perspective, it is difficult to } \\
\text { determine the discount rate. }\end{array}$ \\
\hline & LCC: Life Cycle Cost & $\begin{array}{l}\text { Structures a cost-control } \\
\text { strategy over time, considers } \\
\text { the time value of money. }\end{array}$ & $\begin{array}{l}\text { Does not consider environmental } \\
\text { impact, it is difficult to determine } \\
\text { the discount rate. }\end{array}$ \\
\hline & Social/cultural criteria & $\begin{array}{l}\text { Include qualitative benefits, } \\
\text { assess the additional values } \\
\text { and the co-benefits in } \\
\text { retrofit operations. }\end{array}$ & $\begin{array}{l}\text { It is difficult to assess } \\
\text { non-measurable variables, risk to } \\
\text { be subjective parameters. }\end{array}$ \\
\hline \multirow{3}{*}{ Optimization } & Cost-optimal approaches & $\begin{array}{l}\text { Include both economic and } \\
\text { energy aspects, allow to } \\
\text { identify the most } \\
\text { profitable solution. }\end{array}$ & $\begin{array}{l}\text { Excludes cultural or } \\
\text { social benefits. }\end{array}$ \\
\hline & Optimization algorithms & $\begin{array}{l}\text { Allow consideration of } \\
\text { multiple attributes/objectives } \\
\text { simultaneously, include } \\
\text { feasibility or } \\
\text { technical constraints. }\end{array}$ & $\begin{array}{l}\text { Difficult implementation, require } \\
\text { huge computational time. }\end{array}$ \\
\hline & $\begin{array}{l}\text { Multicriteria/multiattribute } \\
\text { procedures }\end{array}$ & $\begin{array}{l}\text { Include qualitative issues, } \\
\text { merge different aspects } \\
\text { together to provide a } \\
\text { unified assessment. }\end{array}$ & $\begin{array}{l}\text { Require a commission of experts } \\
\text { in the fields of energy efficiency, } \\
\text { architecture, technology, or others. }\end{array}$ \\
\hline Risk and Uncertainty & Sensitivity analyses & $\begin{array}{l}\text { Highlight output variations } \\
\text { according to changes in inputs, } \\
\text { identify the most sensitive } \\
\text { variables in a model. }\end{array}$ & $\begin{array}{l}\text { Do not include correlations or } \\
\text { simultaneous changes } \\
\text { among variables. }\end{array}$ \\
\hline $\begin{array}{c}\text { Tailored } \\
\text { approaches/models }\end{array}$ & $\begin{array}{c}\text { New methodologies } \\
\text { developed by the authors }\end{array}$ & $\begin{array}{l}\text { Introduce integrated } \\
\text { approaches handling building } \\
\text { stocks as a whole. }\end{array}$ & $\begin{array}{l}\text { May require further } \\
\text { implementations on other } \\
\text { case studies. }\end{array}$ \\
\hline
\end{tabular}




\section{Conclusions}

In this review, the available literature on energy retrofit in building stocks was collected and analyzed. The purpose of the article was to clarify which results have already been achieved in this field, summarize prior works and identify common lines of research. Literature gaps were also underlined in order to orientate further studies. This work was conceived to help create a comprehensive basis for future theoretical development.

The scientific community is now facing the responsibility to study strategies and methodologies so as to meet the EU targets on energy efficiency in buildings, as requested by the Directive (EU) 2018/844, with particular attention to national stocks, building portfolios, neighbourhood approaches, and integrated district perspectives.

This study offers a general overview of the most common approaches tested in the field of building retrofits at a stock level. The available literature was collected and analyzed in depth, following a concept centric review procedure. Five major aspects have been identified as fundamental steps to be accomplished. They are energy modelling and assessment, energy retrofit design, decision making criteria assessment, optimal allocation of available resources and risk valuation. However, most of the studies analyzed were focused on single aspects of the process rather than on the bigger picture as a whole. Only a few publications have proposed comprehensive new methodologies to deal with this topic. Most of the research have made reference to standard techniques, such as a reference building approach to asses the energy demand of building stocks categories, a cost-optimal strategy to select the best retrofit design, or a sensitivity analysis to deal with risk.

All these techniques, recommended by the EU regulations (Delegated Regulation 244/2012), have produced successful applications, make for an excellent support to practice and are effective management strategies. Nevertheless, some improvements may still be introduced, leading to the identification of future research challenges.

Energy demand assessment techniques could be more robust and reliable, optimisation strategies may incorporate a broader spectrum of multidisciplinary targets, while risk analysis could also consider different uncertainty methodologies, so as to include simultaneous changes and correlation in input variables. Other considerations may also involve energy retrofit designs and the assessment of decision making criteria regarding the portfolio perspective, since it is challenging to manage dozens of buildings at the same time, without sacrificing accuracy and good details.

The novelty of this work is the joint consideration of the problem, unifying multidisciplinary issues into one single review. Our main contribution is to have gained a critical understanding of this research field, pointing out the latest developments, common problems, and discrepancies. At the same time, some shortcomings may arise from the search boundaries we have selected (language, keywords, country, and search database). During the analysis, several tests have been performed, trying out different combinations of search boundaries, and the chosen ones were considered to the most appropriate and comprehensive. However, future developments of this analysis could broaden the search to wider boundaries including, for instance, other databases or other countries.

This work is intended as the starting point to imagine a decision making procedure for managing energy retrofit projects in large building stocks. Researchers are encouraged to develop better, faster, more reliable, flexible, and straightforward decision support systems to help asset holders to enhance existing stocks, optimizing their cash flows without excluding environmental, cultural, and social targets.

Author Contributions: Conceptualization, A.G.R., L.G. and M.S.; methodology, A.G.R. and L.G.; formal analysis, A.G.R. and L.G.; investigation, A.G.R. and L.G.; resources, A.G.R. and L.G.; data curation, A.G.R. and L.G.; writing-original draft preparation, A.G.R. and L.G.; writing-review and editing, A.G.R., L.G. and M.S.; visualization, A.G.R.; supervision, L.G. and M.S. All authors have read and agreed to the published version of the manuscript.

Funding: This research received no external funding.

Conflicts of Interest: The authors declare no conflict of interest. 


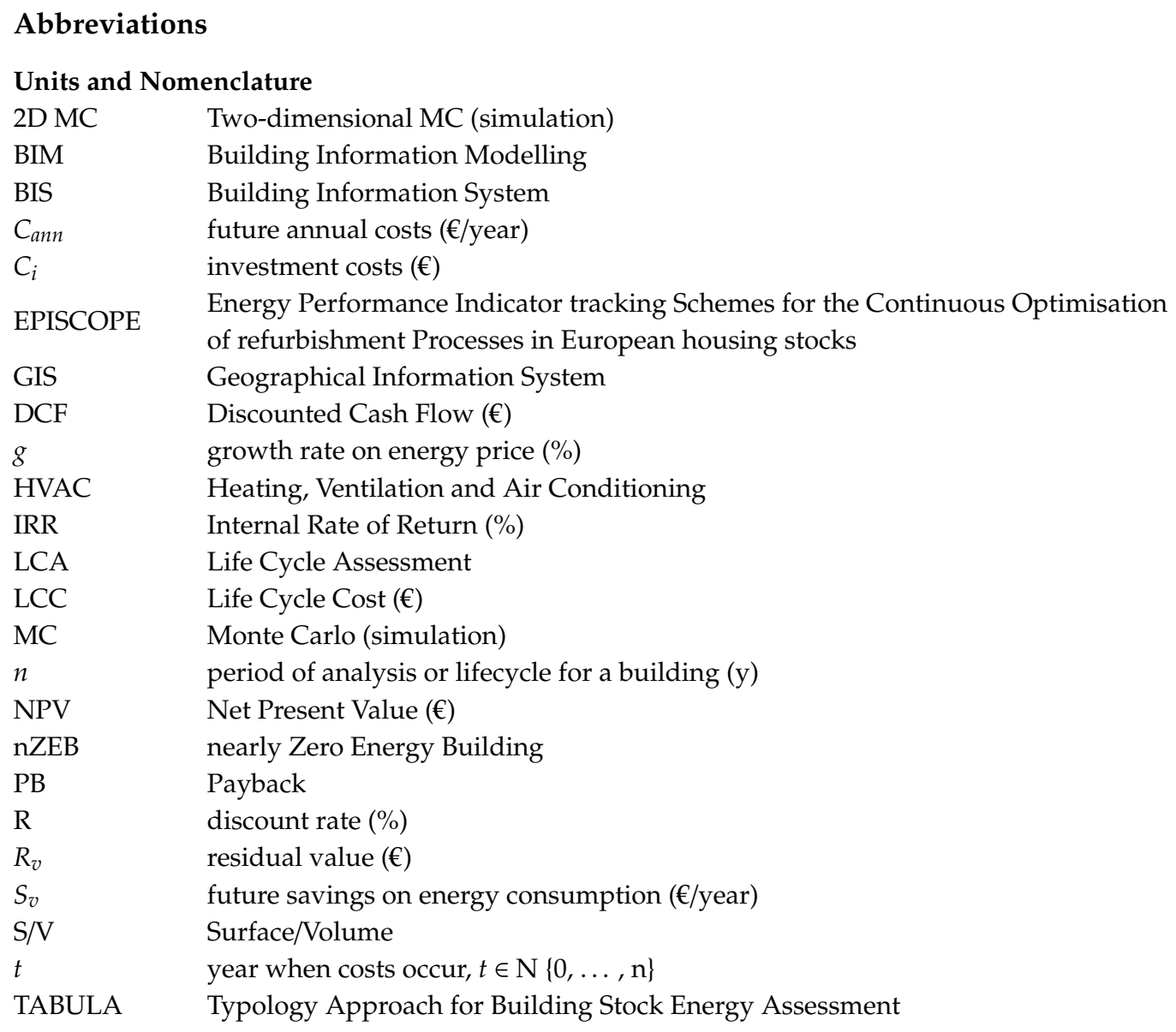

\section{References}

1. Marchi, B.; Zanoni, S. Supply Chain Management for Improved Energy Efficiency: Review and Opportunities. Energies 2017, 10, 1618. [CrossRef]

2. Wang, C.N.; Ho, H.X.T.; Hsueh, M.H. An Integrated Approach for Estimating the Energy Efficiency of Seventeen Countries. Energies 2017, 10, 1597. [CrossRef]

3. Malatji, E.M.; Zhang, J.; Xia, X. A multiple objective optimisation model for building energy efficiency investment decision. Energy Build. 2013, 61, 81-87. [CrossRef]

4. Bisello, A.; Antoniucci, V.; Marella, G. Measuring the price premium of energy efficiency: A two-step analysis in the Italian housing market. Energy Build. 2020, 208, 109670. [CrossRef]

5. Li, L.; Sun, Z. Dynamic Energy Control for Energy Efficiency Improvement of Sustainable Manufacturing Systems Using Markov Decision Process. IEEE Trans. Syst. Man Cybern. Syst. 2013, 43, 1195-1205. [CrossRef]

6. Sandberg, N.H.; Sartori, I.; Heidrich, O.; Dawson, R.; Dascalaki, E.; Dimitriou, S.; Vimm-r, T.; Filippidou, F.; Stegnar, G.; Šijanec Zavrl, M.; et al. Dynamic building stock modelling: Application to 11 European countries to support the energy efficiency and retrofit ambitions of the EU. Energy Build. 2016, 132, 26-38. [CrossRef]

7. Visscher, H.; Dascalaki, E.; Sartori, I. Towards an energy efficient European housing stock: Monitoring, mapping and modelling retrofitting processes. Energy Build. 2016, 132, 1-154. [CrossRef]

8. European Parliament Directive (EU) 2018/844 of the European Parliament and of the council of 30th May 2018 amending Directive 2010/31/EU on the energy performance of buildings and Directive 2012/27/EU on energy efficiency. Off. J. Eur. Union 2018, 2018, 75-91.

9. European Parliament Directive 2010/31/EU of the European Parliament and of the Council of 19 May 2010 on the energy performance of buildings. Off. J. Eur. Union 2010, 334, 13-35. [CrossRef]

10. European Parliament Directive 2012/27/EU of the European Parliament and of the Council of 25 October 2012 on energy efficiency, amending Directives 2009/125/EC and 2010/30/EU and repealing Directives 2004/8/EC and 2006/32/EC. Off. J. Eur. Union 2012, 1-56. [CrossRef] 
11. European Commission Roadmap 2050, European Union. Available online: https://ec.europa.eu/energy/sites/ ener/files/documents/2012_energy_roadmap_2050_en_0.pdf (accessed on 30 June 2020).

12. European Commission Clean Energy for All Europeans. Available online: https://ec.europa.eu/energy/sites/ ener/files/documents/com_860_final.pdf (accessed on 30 June 2020).

13. Webster, J.; Watson, R.T. Analyzing the Past to Prepare for the Future: Writing a Literature Review. MIS Q. 2002, 26. [CrossRef]

14. Järvinen, P. On developing and evaluating of the literature review. In Proceedings of the Workshop on Literature Review in the IRIS31 Conference, Åre, Sweden, 10-13 August 2008.

15. Ahmad, T.; Chen, H.; Guo, Y.; Wang, J. A comprehensive overview on the data driven and large scale based approaches for forecasting of building energy demand: A review. Energy Build. 2018, 165, 301-320. [CrossRef]

16. Swan, L.G.; Ugursal, V.I. Modeling of end-use energy consumption in the residential sector: A review of modeling techniques. Renew. Sustain. Energy Rev. 2009, 13, 1819-1835. [CrossRef]

17. Li, W.; Zhou, Y.; Cetin, K.; Eom, J.; Wang, Y.; Chen, G.; Zhang, X. Modeling urban building energy use: A review of modeling approaches and procedures. Energy 2017, 141, 2445-2457. [CrossRef]

18. Ma, Z.; Cooper, P.; Daly, D.; Ledo, L. Existing building retrofits: Methodology and state-of-the-art. Energy Build. 2012, 55, 889-902. [CrossRef]

19. Pombo, O.; Rivela, B.; Neila, J. The challenge of sustainable building renovation: Assessment of current criteria and future outlook. J. Clean. Prod. 2016, 123, 88-100. [CrossRef]

20. Kheiri, F. A review on optimization methods applied in energy-efficient building geometry and envelope design. Renew. Sustain. Energy Rev. 2018, 92, 897-920. [CrossRef]

21. Nguyen, A.-T.; Reiter, S.; Rigo, P. A review on simulation-based optimization methods applied to building performance analysis. Appl. Energy 2014, 113, 1043-1058. [CrossRef]

22. Tian, W.; Heo, Y.; de Wilde, P.; Li, Z.; Yan, D.; Park, C.S.; Feng, X.; Augenbroe, G. A review of uncertainty analysis in building energy assessment. Renew. Sustain. Energy Rev. 2018, 93, 285-301. [CrossRef]

23. Heidari, M.; Patel, M. Stock modelling and cost-effectiveness analysis of energy-efficient household electronic appliances in Switzerland. Energy Effic. 2020, 13, 571-596. [CrossRef]

24. Carli, R.; Dotoli, M.; Pellegrino, R.; Ranieri, L. A Decision Making Technique to Optimize a Buildings' Stock Energy Efficiency. IEEE Trans. Syst. Man Cybern. Syst. 2017, 47, 794-807. [CrossRef]

25. Oliveira, C.; Coelho, D.; da Silva, P.P. A prospective analysis of the employment impacts of energy efficiency retrofit investment in the Portuguese building stock by 2020. Int. J. Sustain. Energy Plan. Manag. 2014, 2, 81-92. [CrossRef]

26. Luddeni, G.; Krarti, M.; Pernigotto, G.; Gasparella, A. An analysis methodology for large-scale deep energy retrofits of existing building stocks: Case study of the Italian office building. Sustain. Cities Soc. 2018, 41, 296-311. [CrossRef]

27. Singh, M.K.; Mahapatra, S.; Teller, J. An analysis on energy efficiency initiatives in the building stock of Liege, Belgium. Energy Policy 2013, 62, 729-741. [CrossRef]

28. Yılmaz, Y.; Koçlar Oral, G. An approach for an educational building stock energy retrofits through life-cycle cost optimization. Archit. Sci. Rev. 2018, 61, 122-132. [CrossRef]

29. Heidari, M.; Majcen, D.; van der Lans, N.; Floret, I.; Patel, M.K. Analysis of the energy efficiency potential of household lighting in Switzerland using a stock model. Energy Build. 2018, 158, 536-548. [CrossRef]

30. Du, L.; Leivo, V.; Prasauskas, T.; Täubel, M.; Martuzevicius, D.; Haverinen-Shaughnessy, U. Effects of energy retrofits on Indoor Air Quality in multifamily buildings. Indoor Air 2019, 29, 686-697. [CrossRef]

31. Shahrokni, H.; Levihn, F.; Brandt, N. Big meter data analysis of the energy efficiency potential in Stockholm's building stock. Energy Build. 2014, 78, 153-164. [CrossRef]

32. Nappi-Choulet, I.; Décamps, A. Capitalization of energy efficiency on corporate real estate portfolio value. J. Corp. Real Estate 2013, 15, 35-52. [CrossRef]

33. Junghans, A. Decision support model for energy-efficient improvement of entire building stocks. Facilities 2013, 31, 173-184. [CrossRef]

34. Tuominen, P.; Forsström, J.; Honkatukia, J. Economic effects of energy efficiency improvements in the Finnish building stock. Energy Policy 2013, 52, 181-189. [CrossRef] 
35. McKenna, R.; Merkel, E.; Fehrenbach, D.; Mehne, S.; Fichtner, W. Energy efficiency in the German residential sector: A bottom-up building-stock-model-based analysis in the context of energy-political targets. Build. Environ. 2013, 62, 77-88. [CrossRef]

36. Mihic, M.M.; Petrovic, D.C.; Vuckovic, A.M. Energy efficiency project portfolio optimization for public buildings. Metal. Int. 2012, 17, 166-173.

37. Braulio-Gonzalo, M.; Juan, P.; Bovea, M.D.; Ruá, M.J. Modelling energy efficiency performance of residential building stocks based on Bayesian statistical inference. Environ. Model. Softw. 2016, 83, 198-211. [CrossRef]

38. Christen, M.; Adey, B.T.; Wallbaum, H. On the usefulness of a cost-performance indicator curve at the strategic level for consideration of energy efficiency measures for building portfolios. Energy Build. 2016, 119, 267-282. [CrossRef]

39. Uihlein, A.; Eder, P. Policy options towards an energy efficient residential building stock in the EU-27. Energy Build. 2010, 42, 791-798. [CrossRef]

40. Ignjatovic, D.; Ignjatovic, N.C.; Popovic, M.J. Potential for energy efficiency and co2 emission reduction by refurbishment of housing building stock built before 1919 in Serbia. Fresenius Environ. Bull. 2017, 26, 1201-1209.

41. Crockford, D. Sustaining our heritage: The way forward for energy-efficient historic housing stock. Hist. Environ. Policy Pract. 2014, 5, 196-209. [CrossRef]

42. Pallis, P.; Gkonis, N.; Varvagiannis, E.; Braimakis, K.; Karellas, S.; Katsaros, M.; Vourliotis, P. Cost effectiveness assessment and beyond: A study on energy efficiency interventions in Greek residential building stock. Energy Build. 2019, 182, 1-18. [CrossRef]

43. Gabrielli, L.; Ruggeri, A.G. Developing a model for energy retrofit in large building portfolios: Energy assessment, optimization and uncertainty. Energy Build. 2019, 202, 109356. [CrossRef]

44. Abdul Hamid, A.; Bagge, H.; Johansson, D. Measuring the impact of MVHR on the energy efficiency and the IEQ in multifamily buildings. Energy Build. 2019, 195, 93-104. [CrossRef]

45. Ahern, C.; Norton, B. Energy savings across EU domestic building stock by optimizing hydraulic distribution in domestic space heating systems. Energy Build. 2015, 91, 199-209. [CrossRef]

46. Balaras, C.A.; Gaglia, A.G.; Georgopoulou, E.; Mirasgedis, S.; Sarafidis, Y.; Lalas, D.P. European residential buildings and empirical assessment of the Hellenic building stock, energy consumption, emissions and potential energy savings. Build. Environ. 2007, 42, 1298-1314. [CrossRef]

47. Ballarini, I.; Corgnati, S.P.; Corrado, V. Use of reference buildings to assess the energy saving potentials of the residential building stock: The experience of TABULA project. Energy Policy 2014, 68, 273-284. [CrossRef]

48. Beccali, M.; Ciulla, G.; Lo Brano, V.; Galatioto, A.; Bonomolo, M. Artificial neural network decision support tool for assessment of the energy performance and the refurbishment actions for the non-residential building stock in Southern Italy. Energy 2017, 137, 1201-1218. [CrossRef]

49. Belpoliti, V.; Bizzarri, G. A parametric method to assess the energy performance of the social housing stock and simulate suitable retrofit scenarios: An Italian case study. Energy Build. 2015, 96, 261-271. [CrossRef]

50. Brøgger, M.; Bacher, P.; Madsen, H.; Wittchen, K.B. Estimating the influence of rebound effects on the energy-saving potential in building stocks. Energy Build. 2018, 181, 62-74. [CrossRef]

51. Brøgger, M.; Bacher, P.; Wittchen, K.B. A hybrid modelling method for improving estimates of the average energy-saving potential of a building stock. Energy Build. 2019, 199, 287-296. [CrossRef]

52. Csoknyai, T.; Hrabovszky-Horváth, S.; Georgiev, Z.; Jovanovic-Popovic, M.; Stankovic, B.; Villatoro, O.; Szendrő, G. Building stock characteristics and energy performance of residential buildings in Eastern-European countries. Energy Build. 2016, 132, 39-52. [CrossRef]

53. Dall'O', G.; Galante, A.; Pasetti, G. A methodology for evaluating the potential energy savings of retrofitting residential building stocks. Sustain. Cities Soc. 2012, 4, 12-21. [CrossRef]

54. Dall'O', G.; Galante, A.; Torri, M. A methodology for the energy performance classification of residential building stock on an urban scale. Energy Build. 2012, 48, 211-219. [CrossRef]

55. Dascalaki, E.G.; Droutsa, K.G.; Balaras, C.A.; Kontoyiannidis, S. Building typologies as a tool for assessing the energy performance of residential buildings-A case study for the Hellenic building stock. Energy Build. 2011, 43, 3400-3409. [CrossRef]

56. Dascalaki, E.G.; Droutsa, K.; Gaglia, A.G.; Kontoyiannidis, S.; Balaras, C.A. Data collection and analysis of the building stock and its energy performance-An example for Hellenic buildings. Energy Build. 2010, 42, 1231-1237. [CrossRef] 
57. Escandón, R.; Suárez, R.; Sendra, J.J. On the assessment of the energy performance and environmental behaviour of social housing stock for the adjustment between simulated and measured data: The case of mild winters in the Mediterranean climate of southern Europe. Energy Build. 2017, 152, 418-433. [CrossRef]

58. Eriksson, P.; Milić, V.; Brostrom, T. Balancing preservation and energy efficiency in building stocks. Int. J. Build. Pathol. Adapt. 2019. [CrossRef]

59. Florio, P.; Teissier, O. Estimation of the energy performance certificate of a housing stock characterised via qualitative variables through a typology-based approach model: A fuel poverty evaluation tool. Energy Build. 2015, 89, 39-48. [CrossRef]

60. Fracastoro, G.V.; Serraino, M. A methodology for assessing the energy performance of large scale building stocks and possible applications. Energy Build. 2011, 43, 844-852. [CrossRef]

61. Fonseca, J.N.B.; Oliveira Panão, M.J.N. Monte Carlo housing stock model to predict the energy performance indicators. Energy Build. 2017, 152, 503-515. [CrossRef]

62. Gaglia, A.G.; Balaras, C.A.; Mirasgedis, S.; Georgopoulou, E.; Sarafidis, Y.; Lalas, D.P. Empirical assessment of the Hellenic non-residential building stock, energy consumption, emissions and potential energy savings. Energy Convers. Manag. 2007, 48, 1160-1175. [CrossRef]

63. Gangolells, M.; Casals, M.; Forcada, N.; MacArulla, M.; Cuerva, E. Energy mapping of existing building stock in Spain. J. Clean. Prod. 2016, 112, 3895-3904. [CrossRef]

64. Hjortling, C.; Björk, F.; Berg, M.; Klintberg, T.A. Energy mapping of existing building stock in Sweden-Analysis of data from Energy Performance Certificates. Energy Build. 2017, 153, 341-355. [CrossRef]

65. Kalogirou, S.A.; Maxoulis, C.N.; Florides, G.A.; Panayiotou, G.P.; Papadopoulos, A.M.; Neophytou, M.; Fokaides, P.; Georgiou, G.; Symeou, A.; Georgakis, G. The energy behaviour of the residential building stock in cyprus in view of the energy performance of buildings directive implementation. In Proceedings of the CESB 2010 Prague-Central Europe towards Sustainable Building "From Theory to Practice”, Prague, Czech Republic, 30 June-2 July 2010; pp. 1-15.

66. Hoppe, T.; Lulofs, K. The impact of multi-level governance on energy performance in the current Dutch housing stock. Energy Environ. 2008, 19, 819-830. [CrossRef]

67. Mangold, M.; Österbring, M.; Wallbaum, H. Handling data uncertainties when using Swedish energy performance certificate data to describe energy usage in the building stock. Energy Build. 2015, 102, 328-336. [CrossRef]

68. Mastrucci, A.; Baume, O.; Stazi, F.; Leopold, U. Estimating energy savings for the residential building stock of an entire city: A GIS-based statistical downscaling approach applied to Rotterdam. Energy Build. 2014, 75, 358-367. [CrossRef]

69. Nik, V.M.; Sasic Kalagasidis, A. Impact study of the climate change on the energy performance of the building stock in Stockholm considering four climate uncertainties. Build. Environ. 2013, 60, 291-304. [CrossRef]

70. Palma, P.; Gouveia, J.P.; Simoes, S.G. Mapping the energy performance gap of dwelling stock at high-resolution scale: Implications for thermal comfort in Portuguese households. Energy Build. 2019, 190, 246-261. [CrossRef]

71. Perez-Garcia, A.; Guardiola, A.P.; Gómez-Martínez, F.; Guardiola-Víllora, A. Energy-saving potential of large housing stocks of listed buildings, case study: L'Eixample of Valencia. Sustain. Cities Soc. 2018, 42, 59-81. [CrossRef]

72. Pombo, O.; Allacker, K.; Rivela, B.; Neila, J. Sustainability assessment of energy saving measures: A multi-criteria approach for residential buildings retrofitting-A case study of the Spanish housing stock. Energy Build. 2016, 116, 384-394. [CrossRef]

73. Shi, W.; Abdalla, H.; Elsharkawy, H.; Chandler, A. Energy saving of the domestic housing stocks: Application development as a plug-in for energy simulation software. Int. J. Parallel Emergent Distrib. Syst. 2017, 32, S114-S132. [CrossRef]

74. Streicher, K.N.; Padey, P.; Parra, D.; Bürer, M.C.; Patel, M.K. Assessment of the current thermal performance level of the Swiss residential building stock: Statistical analysis of energy performance certificates. Energy Build. 2018, 178, 360-378. [CrossRef]

75. Tommerup, H.; Svendsen, S. Energy savings in Danish residential building stock. Energy Build. 2006, 38, 618-626. [CrossRef]

76. Vogel, J.A.; Lundqvist, P.; Blomkvist, P.; Arias, J. Problem areas related to energy efficiency implementation in Swedish multifamily buildings. Energy Effic. 2016, 9, 109-127. [CrossRef] 
77. Fokaides, P.A.; Polycarpou, K.; Kalogirou, S. The impact of the implementation of the European Energy Performance of Buildings Directive on the European building stock: The case of the Cyprus Land Development Corporation. Energy Policy 2017, 111, 1-8. [CrossRef]

78. Gillich, A.; Saber, E.M.; Mohareb, E. Limits and uncertainty for energy efficiency in the UK housing stock. Energy Policy 2019, 133, 110889. [CrossRef]

79. Guardigli, L.; Bragadin, M.A.; Della Fornace, F.; Mazzoli, C.; Prati, D. Energy retrofit alternatives and cost-optimal analysis for large public housing stocks. Energy Build. 2018, 166, 48-59. [CrossRef]

80. Mata, É.; Kalagasidis, A.S.; Johnsson, F. Energy usage and technical potential for energy saving measures in the Swedish residential building stock. Energy Policy 2013, 55, 404-414. [CrossRef]

81. Semprini, G.; Gulli, R.; Ferrante, A. Deep regeneration vs. shallow renovation to achieve nearly Zero Energy in existing buildings: Energy saving and economic impact of design solutions in the housing stock of Bologna. Energy Build. 2017, 156, 327-342. [CrossRef]

82. Trim, M.J. High rise housing \& a survey of the stock and some methods of refurbishment: Potential for including energy efficiency measures detailed as part of case studies in UK programme. Build. Res. Inf. 1992, 20, 171-175. [CrossRef]

83. Dascalaki, E.G.; Kontoyiannidis, S.; Balaras, C.A.; Droutsa, K.G. Energy certification of Hellenic buildings: First findings. Energy Build. 2013, 65, 429-437. [CrossRef]

84. Ascione, F.; Bianco, N.; Stasio, C.D.; Mauro, G.M. Addressing large-scale energy retrofit of a building stock via representative building samples: Public and private perspectives. Sustainability 2017, 9, 940. [CrossRef]

85. Hamilton, I.G.; Steadman, P.J.; Bruhns, H.; Summerfield, A.J.; Lowe, R. Energy efficiency in the British housing stock: Energy demand and the Homes Energy Efficiency Database. Energy Policy 2013, 60, 462-480. [CrossRef]

86. Simion, C.-P.; Nicolescu, C.; Cioc, M. Selection of energy efficiency projects for dwelling stock to achieve optimal project portfolio at the regional level by applying LCC. An analysis based on three scenarios in the south-muntenia region of Romania. Energies 2018, 11, 1586. [CrossRef]

87. Nägeli, C.; Farahani, A.; Österbring, M.; Dalenbäck, J.-O.; Wallbaum, H. A service-life cycle approach to maintenance and energy retrofit planning for building portfolios. Build. Environ. 2019, 160, 106212. [CrossRef]

88. Economidou, M.; Zangheri, P.; Müller, A.; Kranzl, L. Financing the renovation of the Cypriot building stock: An assessment of the energy saving potential of different policy scenarios based on the INVERT/EE-lab model. Energies 2018, 11, 3071. [CrossRef]

89. Moncada Lo Giudice, G.; Fraticelli, F.; Fornari, F.; Calice, C. Analysis of energy performance of school building stock in Rome. WIT Trans. Ecol. Environ. 2013, 179, 121-129. [CrossRef]

90. Pasquinelli, A.; Agugiaro, G.; Tagliabue, L.C.; Scaioni, M.; Guzzetti, F. Exploiting the potential of integrated public building data: Energy performance assessment of the building stock in a case study in Northern Italy. ISPRS Int. J. Geo-Inform. 2019, 8, 27. [CrossRef]

91. Thygesen, R. An analysis of different solar-assisted heating systems and their effect on the energy performance of multifamily buildings-A Swedish case. Energies 2017, 10, 88. [CrossRef]

92. Carli, R.; Dotoli, M.; Pellegrino, R.; Ranieri, L. Using multi-objective optimization for the integrated energy efficiency improvement of a smart city public buildings' portfolio. In Proceedings of the 11th IEEE International Conference Automation Science Engineering, (CASE2015), Gothenburg, Sweden, 24-28 August 2015; pp. 21-26.

93. Di Giuda, G.M.; Villa, V.; Piantanida, P.; Tagliabue, L.C.; Rinaldi, S.; De Angelis, E.; Ciribini, A.L.C. Progressive Energy Retrofit for the educational building stock in a Smart City. In Proceedings of the 2nd IEEE International Smart Cities Conference (ISC2 2016), Trento, Italy, 12-15 September 2016; pp. 484-489.

94. Vimmr, T.; Enseling, A.; Lützkendorf, T.; Behr, I.; Vache, M.; Beer, A. Decision support tools for economically viable energy efficiency retrofitting in the european rental housing stock. In Proceedings of the Central Europe Towards Sustainable Building 2016: Innovations for Sustainable Future, Prague, Czech Republic, 22-24 June 2016; pp. 1518-1525.

95. Du, L.; Leivo, V.; Martuzevicius, D.; Turunen, M.; Prasauskas, T.; Kiviste, M.; Haverinen-Shaughnessy, U. Development of an assessment protocol: The impact of energy retrofits on indoor environmental quality and public health in the existing building stock. In Proceedings of the Healthy Buildings Europe 2015, HB 2015-Conference Proceedings, Eindhoven, The Netherlands, 18-20 May 2015. 
96. Toleikyte, A.; Bointner, R. Energy efficient design in shopping centres-A pathway towards lower energy consumption: Energy demand scenario modelling until 2030 for the shopping centre building stock in France and Poland. In Proceedings of the 2nd International Conference on Intelligent Green Building and Smart Grid, 2016 IGBSG, Prague, Czech Republic, 27-29 June 2016.

97. Martuzevicius, D.; Prasauskas, T.; Du, L.; Täubel, M.; Leivo, V.; Kiviste, M.; Haverinen-Shaughnessy, U. Energy efficient modernization of housing stock: Demonstration of impacts on indoor environmental quality in northern Europe. In Proceedings of the Healthy Buildings 2015 Europe (HB 2015), International Society of Indoor Air Quality and Climate, Healthy Buildings Conference, Eindhoven, The Netherlands, 18-20 May 2015.

98. Davies, M.; Ridley, I.; Chalabi, Z.; Wilkinson, P.; Hutchinson, E. The health impacts of an energy efficient building stock. In Proceedings of the 12th International Conference on Indoor Air Quality and Climate, Austin, TX, USA, 5-10 June 2011; pp. 1325-1330.

99. Villatoro, O.; Vimmr, T.; Loga, T.; Stein, B. Episcope-Energy performance indicator tracking schemes for the continous optimisation of refurbishment processes in european housing stocks. In Proceedings of the CESB 2016-Central Europe towards Sustainable Building 2016: Innovations for Sustainable Future, Prague, Czech Republic, 22-24 June 2016; pp. 344-351.

100. Pittau, F.; Malighetti, L.E.; Masera, G.; Iannaccone, G. A new modular preassembled timber panel for the energy retrofit of the housing stock. In Proceedings of the World Conference on Timber Engineering WCTE 2016, Vienna, Austria, 22-25 August 2016.

101. Mata, É.; Kalagasidis, A.S.; Johnsson, F. Retrofitting measures for energy savings in the Swedish residential building stock-assessing methodology. In Proceedings of the Thermal Performance of the Exterior Envelopes of Whole Buildings-11th International Conference, Clearwater Beach, FL, USA, 5-9 December 2010.

102. Pittau, F.; Malighetti, L.E.; Iannaccone, G.; Masera, G. Prefabrication as Large-scale Efficient Strategy for the Energy Retrofit of the Housing Stock: An Italian Case Study. In Procedia Engineering, Proceedings of the International High-Performance Built Environment Conference-A Sustainable Built Environment Conference 2016 Series (SBE16), iHBE 2016, Sydney, Australia, 17-18 November 2016; Ding, L., Fiorito, F., Osmond, P., Eds.; Elsevier: Amsterdam, The Netherlands, 2017; Volume 180, pp. 1160-1169.

103. Klobut, K.; Tuominen, P.; Tolman, A.; Adjei, A.; De Best Waldhober, M. How to improve energy efficiency of building stock in the European Union. In Proceedings of the 12th International Conference on Indoor Air Quality and Climate, Austin, TX, USA, 5-10 June 2011; pp. 1325-1330.

104. Elmroth, A.; Jaegbeck, P.O.; Johannesson, C.M.; Hambraeus, M.; Werner, G.; Sors, I. Stockholm project, energy-efficient technology in new multifamily buildings. In Intersol Eighty Five, Proceedings of the Ninth Biennial Congress International Solar Energy Society; Bilgen, E., Hollands, K.G.T., Eds.; Pergamon Press: Oxford, UK, 1986; Volume 2, pp. 940-944.

105. Jagbeck, P.O. Indoor climate in new energy-efficient multi-unit buildings, one part of the "stockholm project" evaluation-A full scale development project. In Indoor Climate in New Energy-Efficient Multi-Unit Buildings, One Part of the "Stockholm Project" Evaluation-A Full Scale Development Project, Proceedings of the Ninth Biennial Congress of the International Solar Energy Society, Montreal, QC, Canada, 23-29 June 1985; Bilgen, E., Hollands, K.G.T., Eds.; Oxford, UK, 1986; pp. 320-324.

106. Corrado, V.; Ballarini, I.; Paduos, S. Assessment of cost-optimal energy performance requirements for the Italian residential building stock. In Energy Procedia, Proceedings of the 68th Conference of the Italian Thermal Machines Engineering Association, ATI 2013, Bologna, Italy, 11-13 September 2013; Morini, G.L., Bianchi, M., C. Saccani, A.C., Eds.; Elsevier: Amsterdam, The Netherlands, 2014; Volume 45, pp. 443-452.

107. Nino Streicher, K.; Parra, D.; Buerer, M.C.; Patel, M.K. Techno-economic potential of large-scale energy retrofit in the Swiss residential building stock. In Energy Procedia, Proceedings of the International Conference on Future Buildings and Districts-Energy Efficiency from Nano to Urban Scale, CISBAT 2017, Lausanne, Switzerland, 6-8 September 2017; Elsevier: Amsterdam, The Netherlands, 2017; Volume 122, pp. 121-126.

108. Zagora, N.; Salihovic, E.; Burazor, M.; Bilalic, S. Transition towards Energy Efficient Housing: Detection of the "weakest Links" in Energy Performance of the Residential Building Stock of Bosnia and Herzegovina. In IOP Conference Series: Materials Science and Engineering; IOP Publishing: Bristol, UK, 2019; Volume 471.

109. Lupisek, A.; Sojková, K.; Volf, M.; Hejtmánek, P. Potential for energy savings in Czech residential building stock by application of a prefabricated mass retrofitting system. In IOP Conference Series: Earth and Environmental Science; IOP Publishing: Bristol, UK, 2019; Volume 323. 
110. Sesana, M.M.; Salvalai, G.; Greslou, O.; Rivallain, M.; Zirngibl, J. Long-Term Renovation Strategies, Energy Voluntary Certification Scheme and Building Renovation Passport: An overview on Energy Performance Certification tools for the European Building stock. In Proceedings of the International Sustainable Built Environment Conference on Resilient Built Environment for Sustainable Mediterranean Countries, SBE, Milan, Italy, 4-5 September 2019; Volume 296.

111. Guolo, E.; Pistore, L.; Romagnoni, P. The role of the reference building in the evaluation of energy efficiency measures for large stocks of public buildings. In E3S Web of Conferences, CLIMA 2019; EDP Sciences: Ulis, France, 2019; Volume 111.

112. Földváry, V.; Bukovianska, H.P.; Petráš, D. Analysis of energy performance and indoor climate conditions of the Slovak housing stock before and after its renovation. In Energy Procedia, Proceedings of the 6th International Building Physics Conference, IBPC 2015, Torino, Italy, 14-17 June 2015; Perino, M., Corrado, V., Eds.; Elsevier: Amsterdam, The Netherlands, 2015; Volume 78, pp. 2184-2189.

113. Ruparathna, R.; Hewage, K.; Sadiq, R. Improving the energy efficiency of the existing building stock: A critical review of commercial and institutional buildings. Renew. Sustain. Energy Rev. 2016, 53, 1032-1045. [CrossRef]

114. Muresan, A.A.; Attia, S. Energy efficiency in the Romanian residential building stock: A literature review. Renew. Sustain. Energy Rev. 2017, 74, 349-363. [CrossRef]

115. Petersdorff, C.; Boermans, T.; Harnisch, J. Mitigation of CO2 emissions from the EU-15 building stock: Beyond the EU Directive on the energy performance of buildings. Environ. Sci. Pollut. Res. 2006, 13, 350-358. [CrossRef]

116. Brøgger, M.; Wittchen, K.B. Estimating the energy-saving potential in national building stocks-A methodology review. Renew. Sustain. Energy Rev. 2018, 82, 1489-1496. [CrossRef]

117. Naber, E.; Volk, R.; Schultmann, F. From the Building Level Energy Performance Assessment to the National Level: How are Uncertainties Handled in Building Stock Models. Procedia Eng. 2017, 180, 1443-1452. [CrossRef]

118. Saha, G.P.; Stephenson, J. A model of residential energy use in New Zealand. Energy 1980, 5, 167-175. [CrossRef]

119. Bentzen, J.; Engsted, T. A revival of the autoregressive distributed lag model in estimating energy demand relationships. Energy 2001, 26, 45-55. [CrossRef]

120. Zhang, Q. Residential energy consumption in China and its comparison with Japan, Canada, and USA. Energy Build. 2004, 36, 1217-1225. [CrossRef]

121. Hirst, E.; Lin, W.; Cope, J. A residential energy use model sensitive to demographic, economic, and technological factors. Q. Rev. Econ. Financ. 1977, 17, 7-22.

122. Labanderia, X.; Labeaga, J.M.; Rodriguez, M. Policy Research A Residential Energy Demand System for Spain. Energy J. 2006, 27, 87-111.

123. Ozturk, H.K.; Canyurt, O.E.; Hepbasli, A.; Utlu, Z. Residential-commercial energy input estimation based on genetic algorithm (GA) approaches: An application of Turkey. Energy Build. 2004, 36, 175-183. [CrossRef]

124. Haas, R.; Schipper, L. Residential energy demand in OECD-countries and the role of irreversible efficiency improvements. Energy Econ. 1998, 20, 421-442. [CrossRef]

125. Nesbakken, R. Price sensitivity of residential energy consumption in Norway. Energy Econ. 1999, 21, 493-515. [CrossRef]

126. Summerfield, A.J.; Lowe, R.J.; Oreszczyn, T. Two models for benchmarking UK domestic delivered energy. Build. Res. Inf. 2010, 38, 12-24. [CrossRef]

127. Fumo, N.; Rafe Biswas, M.A. Regression analysis for prediction of residential energy consumption. Renew. Sustain. Energy Rev. 2015, 47, 332-343. [CrossRef]

128. Catalina, T.; Iordache, V.; Caracaleanu, B. Multiple regression model for fast prediction of the heating energy demand. Energy Build. 2013, 57, 302-312. [CrossRef]

129. Chidiac, S.E.; Catania, E.J.C.; Morofsky, E.; Foo, S. A screening methodology for implementing cost effective energy retrofit measures in Canadian office buildings. Energy Build. 2011, 43, 614-620. [CrossRef]

130. Amiri, S.S.; Mottahedi, M.; Asadi, S. Using multiple regression analysis to develop energy consumption indicators for commercial buildings in the U.S. Energy Build. 2015, 109, 209-216. [CrossRef]

131. Asadi, S.; Amiri, S.S.; Mottahedi, M. On the development of multi-linear regression analysis to assess energy consumption in the early stages of building design. Energy Build. 2014, 85, 246-255. [CrossRef] 
132. Korolija, I.; Zhang, Y.; Marjanovic-Halburd, L.; Hanby, V.I. Regression models for predicting UK office building energy consumption from heating and cooling demands. Energy Build. 2013, 59, 214-227. [CrossRef]

133. Aranda, A.; Ferreira, G.; Mainar-Toledo, M.D.; Scarpellini, S.; Llera Sastresa, E. Multiple regression models to predict the annual energy consumption in the Spanish banking sector. Energy Build. 2012, 49, 380-387. [CrossRef]

134. Parti, M.; Parti, C. The Total and Appliance-Specific Conditional Demand for Electricity in the Household Sector. Bell J. Econ. 1980, 11, 309-321. [CrossRef]

135. Lafrance, G.; Perron, D. Evolution of Residential Electricity Demand by End-Use in Quebec 1979-1989: A Conditional Demand Analysis. Energy Stud. Rev. 1994, 6, 164-173. [CrossRef]

136. Aydinalp-Koksal, M.; Ugursal, V.I. Comparison of neural network, conditional demand analysis, and engineering approaches for modeling end-use energy consumption in the residential sector. Appl. Energy 2008, 85, 271-296. [CrossRef]

137. Matsumoto, S. How do household characteristics affect appliance usage? Application of conditional demand analysis to Japanese household data. Energy Policy 2016, 94, 214-223. [CrossRef]

138. Park, D.C.; Marks, R.J.; Atlas, L.E.; Damborg, M.J. Electric load forecasting using an artificial neural network. IEEE Trans. Power Syst. 1991, 6, 442-449. [CrossRef]

139. Aydinalp, M.; Ugursal, V.I.; Fung, A.S. Modeling of the appliance, lighting and space-cooling energy consumption in the residential sector using neural networks. Appl. Energy 2002, 71, 87-110. [CrossRef]

140. Biswas, M.A.R.; Robinson, M.D.; Fumo, N. Prediction of residential building energy consumption: A neural network approach. Energy 2016, 117, 84-92. [CrossRef]

141. Crawley, D.B.; Hand, J.W.; Kummert, M.; Griffith, B.T. Contrasting The Capabilities Of Building Energy Performance Simulation Programs. Build. Environ. 2008, 43, 661-673. [CrossRef]

142. European Commission. Commission Delegated Regulation (EU) No 244/2012 of 16 January 2012 Supplementing Directive 2010/31/EU of the European Parliament and of the Council on the Energy Performance of Buildings by Establishing a Comparative Methodology Framework for Calculating. Available online: https://eur-lex.europa.eu/LexUriServ/LexUriServ.do?uri=OJ:L:2012:081:0018:0036:EN:PDF (accessed on 30 June 2020).

143. Mauro, G.M.; Hamdy, M.; Vanoli, G.P.; Bianco, N.; Hensen, J.L.M. A new methodology for investigating the cost-optimality of energy retrofitting a building category. Energy Build. 2015, 107, 456-478. [CrossRef]

144. Nägeli, C.; Jakob, M.; Sunarjo, B.; Catenazzi, G. A Building Specific, Economic Building Stock Model to Evaluate Energy Efficiency and Renewable Energy. Proc. CISBAT 2015, 2015, 877-882. [CrossRef]

145. Kavgic, M.; Mavrogianni, A.; Mumovic, D.; Summerfield, A.; Stevanovic, Z.; Djurovic-Petrovic, M. A review of bottom-up building stock models for energy consumption in the residential sector. Build. Environ. 2010, 45, 1683-1697. [CrossRef]

146. Bolliger, R.; Ott, W.; Von Grünigen, S. Finding the balance between energy efficiency measures and renewable energy measures in building renovation: An assessment based on generic calculations in 8 European countries. In Energy Procedia, Proceedings of the 6th International Building Physics Conference, IBPC 2015, Torino, Italy, 14-17 June 2015; Perino, M., Corrado, V., Eds.; Elsevier: Amsterdam, The Netherlands, 2015; Volume 78, pp. 2372-2377.

147. Martinot, E. Energy efficiency and renewable energy in Russia: Transaction barriers, market intermediation, and capacity building. Energy Policy 1998, 26, 905-915. [CrossRef]

148. Akhozheya, B.; Syam, M.; Abdelghani, R.; Aoul, K.A.T. Retrofit evaluation of a residential building in UAE: Energy efficiency and renewable energy. In Proceedings of the 6th Annual International Conference on Architecture and Civil Engineering (ACE2018), Singapore, 14-15 May 2018; pp. 238-242.

149. Pinto, A.; Rodrigues, F.; Mota, A. Geothermal contribution on southern Europe climate for energy efficiency of university buildings. Winter season. In Energy Procedia, Proceedings of the Ninth KES International Conference, Chania, Greece, 5-7 July 2017; Elsevier: Amsterdam, The Netherlands, 2017; Volume 134, pp. 181-191.

150. Eicker, U.; Thumm, F. Energy efficiency and cost effectiveness of low depth geothermal heating and cooling for non-residential buildings. Bauphysik 2012, 34, 11-18. [CrossRef]

151. Basir, A.; Siraj, A.S.; Huq, K.R.M. Analysis of building energy efficiency and integration of renewable energy sources. In Proceedings of the 2015 International Conference on Electrical Engineering and Information Communication Technology (ICEEICT), Dhaka, Bangladesh, 21-23 May 2015; pp. 1-4. 
152. Fathabadi, H. Increasing energy efficiency of PV-converter-battery section of standalone building integrated photovoltaic systems. Energy Build. 2015, 101, 1-11. [CrossRef]

153. Popescu, F.C. Algorithmic design tool for integrating renewable energy infrastructures in buildings: Object oriented design for energy efficiency. In Computer-Aided Architectural Design Futures. The Next City-New Technologies and the Future of the Built Environment. CAAD Futures 2015. Communications in Computer and Information Science; Celani, G., Sperling, D., Franco, J., Eds.; Springer: Berlin/Heidelberg, Germany, 2015; Volume 527, pp. 134-153. ISBN 18650929 (ISSN).

154. Sun, J.M.; Liu, Y.Z. The Application of Renewable Energy in the Building Energy Efficiency. In Applied Mechanics and Materials; Trans Tech Publications, Ltd.: Zurich, Switzerland, 2014; Volume 521, pp. 719-723.

155. Hu, B.; Sun, W.P. Research on green residential buildings based on energy efficiency and renewable energy. Appl. Mech. Mater. 2013, 331, 361-363. [CrossRef]

156. Friedman, C.; Becker, N.; Erell, E. Retrofitting residential building envelopes for energy efficiency: Motivations of individual homeowners in Israel. J. Environ. Plan. Manag. 2018, 61, 1805-1827. [CrossRef]

157. Seifhashem, M.; Capra, B.R.; Milller, W.; Bell, J. The potential for cool roofs to improve the energy efficiency of single storey warehouse-type retail buildings in Australia: A simulation case study. Energy Build. 2018, 158, 1393-1403. [CrossRef]

158. Far, C.; Far, H. Improving energy efficiency of existing residential buildings using effective thermal retrofit of building envelope. Indoor Built Environ. 2018, 28, 744-760. [CrossRef]

159. El-Darwish, I.; Gomaa, M. Retrofitting strategy for building envelopes to achieve energy efficiency. Alexandria Eng. J. 2017, 56, 579-589. [CrossRef]

160. Gagliano, A.; Detommaso, M.; Nocera, F. Assessment of the green roofs thermal dynamic behavior for increasing the building energy efficiencies. Smart Innov. Syst. Technol. 2017, 67, 37-59.

161. Masera, G.; Wakili, K.G.; Stahl, T.; Brunner, S.; Galliano, R.; Monticelli, C.; Aliprandi, S.; Zanelli, A.; Elesawy, A. Development of a Super-insulating, Aerogel-based Textile Wallpaper for the Indoor Energy Retrofit of Existing Residential Buildings. In Procedia Engineering, Proceedings of the International High-Performance Built Environment Conference-A Sustainable Built Environment Conference 2016 Series (SBE16), iHBE 2016, Sydney, Australia, 17-18 November 2016; Ding, L., Fiorito, F., Osmond, P., Eds.; Elsevier: Amsterdam, The Netherlands, 2017; Volume 180, pp. 1139-1149.

162. Nemova, D.V.; Bogomolova, A.K.; Kopylova, A.I. The impact of green roofs on thermal protection and the energy efficiency of buildings. In Advances and Trends in Engineering Sciences and Technologies II, Proceedings of the 2nd International Conference on Engineering Sciences and Technologies, High Tatras Mountains, Tatranské Matliare, Slovak Republic, 29 June-1 July 2016; Mohamad, A.A., Platko, P., Eds.; CRC Press: Boca Raton, FL, USA, 2016; pp. 579-584.

163. Djamila, H.; Rajin, M.; Rizalman, A.N. Energy efficiency through building envelope in Malaysia and Singapore. J. Adv. Res. Fluid Mech. Therm. Sci. 2018, 46, 96-105.

164. Gabor, T.; Dan, V.; Badila, I.-N.; Tiuc, A.-E.; Sur, I.M. Improving the energy efficiency of residential buildings by using a drain water heat recovery system. Environ. Eng. Manag. J. 2017, 16, 1631-1636. [CrossRef]

165. Pukhkal, V.; Vatin, N.; Murgul, V. Central ventilation system with heat recovery as one of the measures to upgrade energy efficiency of historic buildings. Appl. Mech. Mater. 2014, 633-634, 1077-1081. [CrossRef]

166. Wang, Y.; Zhao, F.-Y.; Kuckelkorn, J.; Li, X.-H.; Wang, H.-Q. Indoor air environment and night cooling energy efficiency of a southern German passive public school building operated by the heat recovery air conditioning unit. Energy Build. 2014, 81, 9-17. [CrossRef]

167. Wang, Y.; Zhao, F.-Y.; Kuckelkorn, J.; Liu, D.; Liu, L.-Q.; Pan, X.-C. Cooling energy efficiency and classroom air environment of a school building operated by the heat recovery air conditioning unit. Energy 2014, 64, 991-1001. [CrossRef]

168. Li, X.; Shen, C.; Yu, C.W.F. Building energy efficiency: Passive technology or active technology? Indoor Built Environ. 2017, 26, 729-732. [CrossRef]

169. Ha, P.T.H. Energy efficiency façade design in high-rise apartment buildings using the calculation of solar heat transfer through windows with shading devices. In Proceedings of the 2nd International Conference on Sustainable Development in Civil, Urban and Transportation Engineering CUTE 2018 OP Conference Series: Earth and Environmental Science, Ho Chi Minh City, Vietnam, 17-19 April 2018; Volume 143. 
170. Dong, K.; Lai, J.-Y.; Qian, X.-Q.; Zhan, S.-L.; Ruan, F. Energy efficiency of residential buildings with horizontal external shading in hot summer and cold winter zone. J. Zhejiang Univ. (Eng. Sci.) 2016, 50, 1431-1437. [CrossRef]

171. Cellai, G.; Carletti, C.; Sciurpi, F.; Secchi, S. Transparent building envelope: Windows and shading devices typologies for energy efficiency refurbishments. Green Energy Technol. 2014, 61-118.

172. Chua, K.J.; Chou, S.K. Evaluating the performance of shading devices and glazing types to promote energy efficiency of residential buildings. Build. Simul. 2010, 3, 181-194. [CrossRef]

173. Sanchez, E.; Rolando, A.; Sant, R.; Ayuso, L. Influence of natural ventilation due to buoyancy and heat transfer in the energy efficiency of a double skin facade building. Energy Sustain. Dev. 2016, 33, 139-148. [CrossRef]

174. Wang, Y.; Zhao, F.-Y.; Kuckelkorn, J.; Liu, D.; Liu, J.; Zhang, J.-L. Classroom energy efficiency and air environment with displacement natural ventilation in a passive public school building. Energy Build. 2014, 70, 258-270. [CrossRef]

175. Naamandadin, N.A.; Sapian, A.R.; Noor, S.N.A.M. Site planning and orientation for energy efficiency: A comparative analysis on three office buildings in Kuala Lumpur to determine a location for building shading device. Key Eng. Mater. 2016, 700, 247-255. [CrossRef]

176. Fernandes, L.O; Labaki, L.C. The influence of the shading of surroundings on the brazilian labeling of building energy efficiency. In Proceedings of the 28th International PLEA Conference on Sustainable Architecture + Urban Design: Opportunities, Limits and Needs-Towards an Environmentally Responsible Architecture, Lima, Peru, 7-9 November 2012.

177. De Souza, L.C.L.; Yamaguti, M.L. Orientation, building height and sky view factor as energy efficiency design parameters. In Proceedings of the 24th International conference on Passive and Low Energy Architecture (PLEA 2007), Singapore, 22-24 November 2007; pp. 296-301.

178. Barthelmes, V.; Fabi, V.; Corgnati, S.; Serra, V. Human Factor and Energy Efficiency in Buildings: Motivating End-Users Behavioural Change. In Proceedings of the 20th Congress of the International Ergonomics Association IEA 2018, Florence, Italy, 26-30 August 2019; Volume 825, pp. 514-525.

179. Wang, Y.; Shao, L. Understanding occupancy pattern and improving building energy efficiency through Wi-Fi based indoor positioning. Build. Environ. 2017, 114, 106-117. [CrossRef]

180. Huovila, A.; Tuominen, P.; Airaksinen, M. Effects of building occupancy on indicators of energy efficiency. Energies 2017, 10, 628. [CrossRef]

181. Yang, Z.; Becerik-Gerber, B. How does building occupancy influence energy efficiency of HVAC systems? In Energy Procedia, Proceedings of the Applied Energy Symposium and Summit on Low-Carbon Cities and Urban Energy Systems, CUE 2015, Fuzhou, China, 15-17 November 2015; Elsevier: Amsterdam, The Netherlands, 2016; Volume 88, pp. 775-780.

182. Marshall, E.; Steinberger, J.K.; Dupont, V.; Foxon, T.J. Combining energy efficiency measure approaches and occupancy patterns in building modelling in the UK residential context. Energy Build. 2016, 111, 98-108. [CrossRef]

183. Wang, Z.; Wang, L. Occupancy pattern based intelligent control for improving energy efficiency in buildings. In Proceedings of the 2012 IEEE International Conference on Automation Science and Engineering: Green Automation Toward a Sustainable Society. CASE 2012, Seoul, Korea, 20-24 August 2012; pp. 804-809.

184. Ruggeri, A.G.; Calzolari, M.; Scarpa, M.; Gabrielli, L.; Davoli, P. Planning energy retrofit on historic building stocks: A score-driven decision support system. Energy Build. 2020, 224, 110066. [CrossRef]

185. De Santoli, L. Guidelines on energy efficiency of cultural heritage. Energy Build. 2015, 86, 534-540. [CrossRef]

186. Dalla Negra, R.; Ambrogio, K.; Zuppiroli, M. Miglioramento dell'efficienza energetica in sistemi aggregati di edilizia storica: Tra istanze conservative e prestazionali, potenzialità di ricerca ed approcci operativi. In $\mathrm{Il}$ Recupero Energetico Ambientale del Costruito; Davoli, P., Ed.; Maggioli: Santarcangelo di Romagna, Italy, 2010; pp. 29-37.

187. Webb, A.L. Energy retrofits in historic and traditional buildings: A review of problems and methods. Renew. Sustain. Energy Rev. 2017, 77, 748-759. [CrossRef]

188. Ascione, F.; Ceroni, F.; De Masi, R.F.; de' Rossi, F.; Pecce, M.R. Historical buildings: Multidisciplinary approach to structural/energy diagnosis and performance assessment. Appl. Energy 2017, 185, 1517-1528. [CrossRef] 
189. Pisello, A.L.; Petrozzi, A.; Castaldo, V.L.; Cotana, F. On an innovative integrated technique for energy refurbishment of historical buildings: Thermal-energy, economic and environmental analysis of a case study. Appl. Energy 2014, 162, 1313-1322. [CrossRef]

190. Ascione, F.; Cheche, N.; De Masi, R.F.; Minichiello, F.; Vanoli, G.P. Design the refurbishment of historic buildings with the cost-optimal methodology: The case study of a XV century Italian building. Energy Build. 2015, 99, 162-176. [CrossRef]

191. Roberti, F.; Oberegger, U.F.; Lucchi, E.; Troi, A. Energy retrofit and conservation of a historic building using multi-objective optimization and an analytic hierarchy process. Energy Build. 2017, 138, 1-10. [CrossRef]

192. Fabbri, R.; Gabrielli, L.; Ruggeri, A.G. Interactions between restoration and financial analysis: The case of Cuneo War Wounded House. J. Cult. Herit. Manag. Sustain. Dev. 2018, 8, 145-161. [CrossRef]

193. Posani, M.; Veiga, M.; Freitas, V. Historic buildings resilience: A view over envelope energy retrofit possibilities. In Proceedings of the 8th International Conference on Building Resilience, Lisbon, Portugal, 14-16 November 2018.

194. Lucchi, E. Energy Efficiency in Historic Buildings: A Tool for Analysing the Compatibility, Integration and Reversibility of Renewable Energy Technologies. In Proceedings of the World Renewable Energy Congress, Linköping, Sweden, 8-13 May 2011.

195. Jones, C.; Hammond, G. Embodied energy and carbon in construction materials. Energy 2008, 161, 87-98. [CrossRef]

196. Langston, Y.L.; Langston, C.A. Reliability of building embodied energy modelling: An analysis of 30 Melbourne case studies. Constr. Manag. Econ. 2008, 26, 147-160. [CrossRef]

197. Mangan, S.D.; Oral, G.K. Life cycle assessment of energy retrofit strategies for an existing residential building in Turkey. A/Z ITU J. Fac. Archit. 2016, 13, 143-156. [CrossRef]

198. Mangan, S.D.; Oral, G.K. A study on life cycle assessment of energy retrofit strategies for residential buildings in Turkey. In Energy Procedia, Proceedings of the 6th International Building Physics Conference IBPC 2015, Torino, Italy, 14-17 June 2015; Perino, M., Corrado, V., Eds.; Elsevier: Amsterdam, The Netherlands, 2015; Volume 78, pp. 842-847.

199. Cellura, M.; Guarino, F.; Longo, S.; Mistretta, M. Energy life-cycle approach in Net zero energy buildings balance: Operation and embodied energy of an Italian case study. Energy Build. 2014, 72, 371-381. [CrossRef]

200. Kohler, N.A. Analyse Énergétique de la Construction de l'utilisation et de la Démolition de Bâtiments; Ecole Polytechnique Federale Lausanne: Lausanne, Switzerland, 1986.

201. Berg, F.; Fuglseth, M. Life cycle assessment and historic buildings: Energy-efficiency refurbishment versus new construction in Norway. J. Archit. Conserv. 2018, 24, 152-167. [CrossRef]

202. Ingrao, C.; Messineo, A.; Beltramo, R.; Yigitcanlar, T.; Ioppolo, G. How can life cycle thinking support sustainability of buildings? Investigating life cycle assessment applications for energy efficiency and environmental performance. J. Clean. Prod. 2018, 201, 556-569. [CrossRef]

203. Sartori, I.; Hestnes, A.G. Energy use in the life cycle of conventional and low-energy buildings: A review article. Energy Build. 2007, 39, 249-257. [CrossRef]

204. Ibn-Mohammed, T.; Greenough, R.; Taylor, S.; Ozawa-Meida, L.; Acquaye, A. Operational vs. embodied emissions in buildings-A review of current trends. Energy Build. 2013, 66, 232-245. [CrossRef]

205. Copiello, S. Building energy efficiency: A research branch made of paradoxes. Renew. Sustain. Energy Rev. 2017, 69, 1064-1076. [CrossRef]

206. De Mare, G.; Morano, P. La Stima del Costo delle Opere Pubbliche; UTET: Torino, Italy, 2002.

207. Simonotti, M. Metodi di Stima Immobiliare; Dario Flac.: Palermo, Italy, 2006.

208. Collegio degli Ingegneri e Architetti di Milano. Prezzi Tipologie Edilizie; DEI: Roma, Italy, 2014.

209. Dirutigliano, D.; Delmastro, C.; Torabi Moghadam, S. A multi-criteria application to select energy retrofit measures at the building and district scale. Therm. Sci. Eng. Prog. 2018, 6, 457-464. [CrossRef]

210. Espen, L. Use of multicriteria decision analysis methods for energy planning problems. Renew. Sustain. Energy Rev. 2007, 11, 1584-1595. [CrossRef]

211. Ascione, F.; Bianco, N.; Mauro, G.M.; Napolitano, D.F.; Vanoli, G.P. A multi-criteria approach to achieve constrained cost-optimal energy retrofits of buildings by mitigating climate change and urban overheating. Climate 2018, 6, 37. [CrossRef]

212. Civic, A.; Vucijak, B. Multi-criteria optimization of insulation options for warmth of buildings to increase energy efficiency. Procedia Eng. 2014, 69, 911-920. [CrossRef] 
213. Donnarumma, G.; Fiore, P. A multi-criteria model for the comparison of building envelope energy retrofits. In AIP Conference Proceedings; AIP Publishing LLC.: Melville, NY, USA, 2017; Volume 1814.

214. Arumägi, E.; Kalamees, T. Analysis of energy economic renovation for historic wooden apartment buildings in cold climates. Appl. Energy 2014, 115, 540-548. [CrossRef]

215. Copiello, S.; Gabrielli, L.; Bonifaci, P. Evaluation of energy retrofit in buildings under conditions of uncertainty: The prominence of the discount rate. Energy 2017, 137, 104-117. [CrossRef]

216. Barthelmes, V.M.; Becchio, C.; Bottero, M.; Corgnati, S.P. Cost-optimal analysis for the definition of energy design strategies: The case of a Nearly-Zero Energy Building. Valori e Valutazioni 2016, 16, 57-70.

217. Bleyl, J.W.; Bareit, M.; Casas, M.A.; Chatterjee, S.; Coolen, J.; Hulshoff, A.; Lohse, R.; Mitchell, S.; Robertson, M.; Ürge-Vorsatz, D. Office building deep energy retrofit: Life cycle cost benefit analyses using cash flow analysis and multiple benefits on project level. Energy Effic. 2018, 12, 261-279. [CrossRef]

218. Çetintaş, K.F.; Yilmaz, Z. Optimization of thermal insulation material and thickness for building energy efficiency in Mediterranean climates based on life cycle perspective. A/Z ITU J. Fac. Archit. 2017, 14, 99-112. [CrossRef]

219. Giuseppe, E.D.; Massi, A.; D’Orazio, M. Impacts of Uncertainties in Life Cycle Cost Analysis of Buildings Energy Efficiency Measures: Application to a Case Study. In Energy Procedia, Proceedings of 8th International Conference on Sustainability in Energy and Buildings, SEB-16, Turin, Italy, 11-13 September 2016; Howlett, A.R., Capozzoli, V.S., Eds.; Elsevier: Amsterdam, The Netherlands, 2017; Volume 111, pp. 442-451. [CrossRef]

220. Amstalden, R.W.; Kost, M.; Nathani, C.; Imboden, D.M. Economic potential of energy-efficient retrofitting in the Swiss residential building sector: The effects of policy instruments and energy price expectations. Energy Policy 2007, 35, 1819-1829. [CrossRef]

221. Kumbaroglu, G.; Madlener, R. Evaluation of economically optimal retrofit investment options for energy savings in buildings. Energy Build. 2012, 49, 327-334. [CrossRef]

222. Brotman, B.A. Green office construction: A discounted after-tax cash flow analysis. J. Prop. Investig. Financ. 2014, 32, 474-484. [CrossRef]

223. Wyatt, P. Property Valuation: Second Edition; Wiley-Blac.: Oxford, UK, 2013.

224. Remer, D.S.; Nieto, A.P. A compendium and comparison of 25 project evaluation techniques. Part 1: Net present value and rate of return methods. Int. J. Prod. Econ. 1995, 42, 79-96. [CrossRef]

225. Remer, D.S.; Nieto, A.P. A compendium and comparison of 25 project evaluation techniques. Part 2: Ratio, payback, and accounting methods. Int. J. Prod. Econ. 1995, 42, 101-129. [CrossRef]

226. Petersen, S.; Svendsen, S. Method for component-based economical optimisation for use in design of new low-energy buildings. Renew. Energy 2012, 38, 173-180. [CrossRef]

227. Verbeeck, G.; Hens, H. Energy savings in retrofitted dwellings: Economically viable? Energy Build. 2005, 37, 747-754. [CrossRef]

228. Bottarelli, M.; Gabrielli, L. Payback period for a ground source heat pump system. Int. J. Heat Technol. 2011, 29, 145-150.

229. Kneifel, J. Life-cycle carbon and cost analysis of energy efficiency measures in new commercial buildings. Energy Build. 2010, 42, 333-340. [CrossRef]

230. Bartolini, N.; Della Fornace, F.; Gulli, R.; Mazzoli, C.; Prati, D. Misurare la qualitàcomplessiva degli edifici. Il protocollo BQE (Building Quality Evaluation). In L'evoluzione del Sapere in Architettura Tecnica; Maggioli: Milano, Italy, 2016; pp. 43-52.

231. Baños, R.; Manzano-Agugliaro, F.; Montoya, F.G.; Gil, C.; Alcayde, A.; Gómez, J. Optimization methods applied to renewable and sustainable energy: A review. Renew. Sustain. Energy Rev. 2011, 15, 1753-1766. [CrossRef]

232. Wang, B.; Xia, X.; Zhang, J. A multi-objective optimization model for the life-cycle cost analysis and retrofitting planning of buildings. Energy Build. 2014, 77, 227-235. [CrossRef]

233. Schütz, T.; Schiffer, L.; Harb, H.; Fuchs, M.; Müller, D. Optimal design of energy conversion units and envelopes for residential building retrofits using a comprehensive MILP model. Appl. Energy 2017, 185, 1-15. [CrossRef]

234. Ashouri, A.; Fux, S.S.; Benz, M.J.; Guzzella, L. Optimal design and operation of building services using mixed-integer linear programming techniques. Energy 2013, 59, 365-376. [CrossRef]

235. Di Pilla, L.; Desogus, G.; Mura, S.; Ricciu, R.; Di Francesco, M. Optimizing the distribution of Italian building energy retrofit incentives with Linear Programming. Energy Build. 2016, 112, 21-27. [CrossRef] 
236. Kershaw, T.; Eames, M.; Coley, D. Comparison of multi-year and reference year building simulations. Build. Serv. Eng. Res. Technol. 2010, 31, 357-369. [CrossRef]

237. Smith, A.; Luck, R.; Mago, P.J. Analysis of a combined cooling, heating, and power system model under different operating strategies with input and model data uncertainty. Energy Build. 2010, 42, 2231-2240. [CrossRef]

238. Wang, L.; Mathew, P.; Pang, X. Uncertainties in energy consumption introduced by building operations and weather for a medium-size office building. Energy Build. 2012, 53, 152-158. [CrossRef]

239. Eguaras-Martínez, M.; Vidaurre-Arbizu, M.; Martín-Gómez, C. Simulation and evaluation of building information modeling in a real pilot site. Appl. Energy 2014, 114, 475-484. [CrossRef]

240. Gu, Y.; Zhang, X.; Are Myhren, J.; Han, M.; Chen, X.; Yuan, Y. Techno-economic analysis of a solar photovoltaic/thermal (PV/T) concentrator for building application in Sweden using Monte Carlo method. Energy Convers. Manag. 2018, 165, 8-24. [CrossRef]

241. Zhu, Y.; Tao, Y.; Rayegan, R. A comparison of deterministic and probabilistic life cycle cost analyses of ground source heat pump (GSHP) applications in hot and humid climate. Energy Build. 2012, 55, 312-321. [CrossRef]

242. Kemp, A.G.; Stephen, L. Price, cost and exploration sensitivities of prospective activity levels in the UKCS: An application of the Monte Carlo technique. Energy Policy 1999, 27, 801-810. [CrossRef]

243. Sun, Y. Closing the Building Energy Performance Gap by Improving Our Predictions. Ph.D. Dissertation, Georgia Institute of Technology, Atlanta, GA, USA, 2014.

244. Wang, Q. Accuracy, Validity and Relevance of Probabilistic Building Energy Models. Ph.D. Thesis, Georgia Institute of Technology, Atlanta, GA, USA, 2016.

245. Arendt, P.D.; Apley, D.W.; Chen, W. Quantification of Model Uncertainty: Calibration, Model Discrepancy, and Identifiability. J. Mech. Des. 2012, 134, 1-40. [CrossRef]

246. Silva, A.S.; Ghisi, E. Uncertainty analysis of user behaviour and physical parameters in residential building performance simulation. Energy Build. 2014, 76, 381-391. [CrossRef]

247. Ragas, A.M.J.; Brouwer, F.P.E.; Büchner, F.L.; Hendriks, H.W.M.; Huijbregts, M.A.J. Separation of uncertainty and interindividual variability in human exposure modeling. J. Expo. Sci. Environ. Epidemiol. 2009, 19, 201-212. [CrossRef] [PubMed]

248. Zheng, J.; Frey, H.C. Quantitative analysis of variability and uncertainty with known measurement error: Methodology and case study. Risk Anal. 2005, 25, 663-675. [CrossRef] [PubMed]

249. Heo, Y.; Graziano, D.; Guzowski, L.; Muehleisen, R. Evaluation of calibration efficacy under different levels of uncertainty. J. Build. Perform. Simul. 2015, 8, 135-144. [CrossRef]

250. Boussabaine, A.; Kirkham, R. Whole Life-Cycle Costing: Risk and Risk Responses; Blackwell Publishing: Oxford, UK, 2004.

251. Tian, W. A review of sensitivity analysis methods in building energy analysis. Renew. Sustain. Energy Rev. 2013, 20, 411-419. [CrossRef]

252. Napoli, G.; Gabrielli, L.; Barbaro, S. The efficiency of the incentives for the public buildings energy retrofit. The case of the Italian regions of the "objective convergence". Valori e Valutazioni 2017, 18, 25-39.

253. Loizou, P.; French, N. Risk and uncertainty in development. J. Prop. Investig. Financ. 2012, 30, $198-210$. [CrossRef]

254. de Wilde, P.; Tian, W. Identification of key factors for uncertainty in the prediction of the thermal performance of an office building under climate change. Build. Simul. 2009, 2, 157-174. [CrossRef]

255. French, N.; Gabrielli, L. Uncertainty and feasibility studies: An Italian case study. J. Prop. Investig. Financ. 2006, 24, 49-67. [CrossRef]

256. Prada, A.; Cappelletti, F.; Baggio, P.; Gasparella, A. On the effect of material uncertainties in envelope heat transfer simulations. Energy Build. 2014, 71, 53-60. [CrossRef]

257. Biegler, L.; Biros, G.; Ghattas, O.; Heinkenschloss, M.; Keyes, D.; Mallick, B.; Marzouk, Y.; Tenorio, L.; van Bloemen Waanders, B.; Willcox, K. Large-Scale Inverse Problems and Quantification of Uncertainty; John Wiley: Hoboken, NJ, USA, 2011.

(C) 2020 by the authors. Licensee MDPI, Basel, Switzerland. This article is an open access article distributed under the terms and conditions of the Creative Commons Attribution (CC BY) license (http://creativecommons.org/licenses/by/4.0/). 